\title{
Development of a Specific Monoclonal Antibody based Sandwich ELISA for Rapid Detection of Haemorrhagic Septicemia in Bovine Blood
}

\author{
Ragini Hazari ${ }^{1 *}$, Arvind Kumar ${ }^{1}$ and Sonu Sharma ${ }^{2}$ \\ ${ }^{1}$ Department of Veterinary Microbiology, ${ }^{2}$ Department of Veterinary Pathology, Lala Lajpat \\ Rai University of Veterinary and Animal Sciences, Hisar, Haryana, India \\ *Corresponding author
}

\section{Keywords \\ Monoclonal antibody, Sandwich ELISA, Pasteurella multocida}

Article Info

Accepted: 12 April 2019 Available Online: 10 May 2019

\section{A B S T R A C T}

As infection with Pasteurella multocida is common in cattle and buffalo, a monoclonal antibody based sandwich ELISA kit was developed for its rapid and easy detection. The test was optimized and standardized so that maximum concordance could be maintained with the standard procedures of hemorrhagic septicemia diagnosis recommended by the WHO expert committee. HS-1, a Pasteurella multocida type B specific monoclonal antibody developed in mice was used as tracing antibody to capture $P$. multocida serotype B:2 in a sandwich ELISA. The test was standardized for whole killed bacterial cell, sonicated and the LPS antigens of P. multocida type B:2. An anti-pasteurella hyper immune serum raised in rabbit acted as the coating antibody was selected since it was previously shown to be a major immunogen during $P$. multocida infection in rabbits and contain antibodies against several conserved epitopes. The sensitivity of the sandwich ELISA determined with ELISA well module (8x2) for whole killed bacterial cells, and with two fold serial dilutions of an antigen (12 steps and in triplicate) for sonicated and LPS antigen, were $1.6 \times 10^{11} \mathrm{cfu} / \mathrm{ml}, 385 \mathrm{ng} / \mathrm{ml}$ and $17.4 \mathrm{mg} / \mathrm{ml}$ respectively. Specificity, evaluated against the cultured P. multocida type A antigen of bovine strain, was $100 \%$. The coefficient of variation for sonicated and the LPS antigens calculated from intra and inter plate for same-day and inter-day tests were found within $20 \%$ indicating good reproducibility with few exceptions when $\mathrm{CV}$ varied more than $20 \%$. In some instances, $\mathrm{CV}$ values as high as $23 \%$ and $25 \%$ were recorded for whole killed bacterial cell. CV values up to $25 \%$ indicated repeatability of the ELISA and higher OD values for whole killed bacterial cells did not record high standard deviations (SD). Therefore, the ELISA showed repeatability of the test for all three types of antigens. Furthermore, more expression of the $P$. multocida type $\mathrm{B}: 2$ specific $\mathrm{PCR}$ in comparison to $P$. multocida type $\mathrm{B}$ and P. multocida PCR in early phase of pathogenesis of the disease was detected and showed the greater analytical sensitivity and specificity to identify bovines infected with $P$. multocida. The results showed that this sandwich ELISA, with good specificity, sensitivity and simplicity, would be a useful assay for an early clinical diagnosis of HS. The ELISA can be performed directly on infected blood in modestly equipped laboratory, manned by semi skilled personnel. 


\section{Introduction}

Hemorrhagic Septicemia (HS) is a major disease of cattle and buffaloes occurring as epizootics in many Asian and African countries. It is caused by specific serotypes within the bacterial species of Gram negative coccobacillary pathogen Pasteurella multocida viz. $\mathrm{B}: 2$ and $\mathrm{B}: 5$ in Asian counties and type E:2 in African countries (Carter and De Alwis, 1989). On the basis of capsular antigens, $P$. multocida has been classified into five serotypes, namely A, B, D, E and F (Carter, 1955), whereas on the basis of somatic antigens, it has been classified into sixteen serotypes (Heddleston et al., 1972). According to current classification, the family Pasteurellaceae includes a large group of Gram negative bacteria that are chemoorganotrophic, facultatively anaerobic and fermentative in nature (Mutters et al., 1989). It is a disease of utmost economic importance particularly in Asia due to large population of buffaloes. The case fatality rate and susceptibility to HS are higher in buffaloes than in cattle (Benkirane and De Alwis, 2002). HS has been estimated to cause huge economic losses in India, to the tune of Rs. 225 millions (Singh et al., 2008). However, the losses are expected to be much greater than that have been reported because of poor reporting and surveillance systems.

Once clinical signs appear, case fatality is nearly $100 \%$. Variable number of immune carriers is present in animal populations, particularly in endemic areas. They may be latent carriers, where the organisms are lodged in the tonsils, or active carriers, where organisms are detectable in the naso-pharynx. The long lasting carrier status may escape the notice of the animal health authorities but may be of considerable economic significance (De Alwis, 1981). HS is, typically a septicemic disease that develops following release of endotoxin from dead bacterial cells.
It has an affinity for respiratory tract mucus membrane (Lettellier et al., 1991) and a better affinity for non-ciliated respiratory epithelial cells (Pijoan and Trigo, 1990).

The pathogenic components of $P$. multocida include capsule, endotoxin and outer membrane proteins which have been reported to be the virulence factors responsible for immuno-pathological changes (Boyce and Adler, 2006; Singh et al., 2011).

Regular vaccination at six months interval, before onset of rainy season and beginning of winter, is a major control measure for prevention of HS. Various killed vaccines, for example, broth bacterin, aluminum hydroxide precipitated vaccine and the oil adjuvant vaccine, are commonly used for immunization against HS (Tasneem et al., 2009). Short duration of immunity of only 4-6 months is a major limitation of the conventional killed bacterial vaccines. Oil adjuvanted vaccine induces immunity of little longer duration of about 9 months, yet far lower than that needed (De Alwis, 1992a; OIE, 2012). For improving the duration of immunity, live vaccine with aroA mutant has been experimentally developed and a live vaccine using deer strain (P. multocida $\mathrm{B}: 3,4)$ has also been reported (Verma and Jaiswal, 1998). The live vaccine of deer strain is used only in Myanmar (De Alwis, 1999).

It is a common practice that antibiotics are used to treat the diseased animals. HS is a septicemic disease and the animal dies of endotoxic shock (Horadagoda et al., 2001). The bacteria multiply fast in the blood of diseased animals and die. Release of LPS (endotoxin) from dead bacterial cell causes endotoxic shock and death of the animal. Treatment with antibiotics after appearance of clinical signs (fever and recumbency), may hasten the rate of death of bacterial cells in the blood. This may further exacerbate the 
condition and hasten the death of animal (De Alwis, 1999). Inadequate vaccination based control programme and difficulties of antibiotic treatment at later stage of the disease, put emphasis on development of not only a specific and a sensitive diagnostic test but use of the test should also reduce time taken for diagnosis (time spent on collection and reaching of samples to the lab as well as time needed to complete the test procedure). The test of high sensitivity would detect smaller amount of antigen in clinical samples and therefore may have capacity for diagnosis at an early stage, before the onset of clinical symptoms. Point-of-care diagnostics would reduce the time taken for diagnosis. Therefore, a highly sensitive point-of-care diagnostics is an ideal test.

The polymerase chain reaction (PCR) assay has been reported for amplification of $P$. multocida gene, $P$. multocida type $\mathrm{B}$ and $P$. multocida B:2 (Brickell et al., 1998 and Townsend et al., 1998). PCR is a rapid, specific and highly sensitive test for confirmation of $\mathrm{HS}$ but it requires sophisticated laboratory and highly skilled manpower. Therefore, PCR could not be developed as point-of-care diagnostic test. The PCR can detect even very little amount of target DNA in the infected blood. Despite its very high sensitivity, time taken for collection, dispatch and receipt of samples in laboratory and time taken for completion of procedure of PCR defeats its use for diagnosing the disease at an early stage.

Attempts have been made to develop simple agglutination test as point-of-care diagnostic test. Use of agglutinating monoclonal antibody coated coloured latex beads based agglutination has given desired sensitivity and specificity for clinical diagnosis of the disease (Pankaj Kumar and Arvind Kumar, Indian Patent Application No. 767/DEL/2015 filed on March 20, 2015). The latex agglutination test is not an objective test and therefore, an inexperienced operator may cause error of judgment.

It is, therefore necessary to develop simple, accurate and rapid diagnostic test that can be carried out by semi-skilled laboratory personnel even in the modestly equipped laboratories at block or district level. ELISA has been successfully used for diagnosis of various bacterial and viral diseases (OIE, 2012). The test can also be converted as a kit for use as point-of-care diagnostics (Anon, 2004, Lister et al., 2012). Dawkins et al., (1990) developed an ELISA for detection of P. multocida B:2. However, the test has been described as a useful tool for screening of bacterial isolates and is based on polyclonal serum. Use of polyclonal serum raises a doubt on specificity of the test. Perusal of scientific literature did not show the use of test as field diagnostic test for HS.

Monoclonal antibodies have been described as bio-reagent of unmatched specificity that can distinguish even very closely related micro-organisms and of very high sensitivity because of no undesired cross reactive back ground reactions in ELISA. Polyclonal serum may contain antibodies against several conserved epitopes and therefore, polyclonal serum shows cross reactivity in ELISA. The conserved epitopes are generally immunodominant epitopes and the epitopes discriminating closely related microorganisms are immunosubdominant epitopes. Low amount of antibody against such immunosubdominant epitopes(s) would lower sensitivity of the test. The specificity and sensitivity of the ELISA test are expected to increase many folds with $P$. multocida B specific monoclonal antibody and is therefore suitable for early diagnosis of the disease. The test could also be converted in to point-ofcare diagnostic test. A $P$. multocida $\mathrm{B}$ specific monoclonal antibody has been developed in 
our laboratory (Pankaj Kumar, 2014). Considering the fact that the matrix of clinical sample would be the infected blood, a sandwich ELISA would be more suited for the purpose. The ELISA plate wells coated with anti-pasteurella multocida polyclonal serum would selectively capture the $P$. multocida antigen present in the sample and then P. multocida B specific monoclonal antibody would bind only to captured $P$. multocida type $\mathrm{B}$ bacteria/antigens. This study is therefore targeted to Development and optimization of monoclonal antibody sandwich ELISA for diagnosis of Hemorrhagic Septicemia of bovines and evaluation of the test for clinical diagnosis of Hemorrhagic Septicemia.

\section{Materials and Methods}

\section{The bacteria}

Buffalo calf blood experimentally infected with $P$. multocida $\mathrm{B}: 2 \mathrm{P}_{52}$ (Vaccine strain) was obtained from Haryana Veterinary Vaccine Institute (HVVI), Hisar. The bacterial stock was prepared by streaking the infected blood on 5\% sheep blood agar and incubated overnight at $35-36^{\circ} \mathrm{C}$. The bacterial growth on the Petri plate was agar washed and aliquoted in $50 \%$ brain heart infusion broth (BHI broth) and glycerol. The aliquots were stored at $-20^{\circ} \mathrm{C}$. The bacteria were revived as and when required, by streaking on $5 \%$ sheep blood agar and incubated overnight at $35-36^{\circ} \mathrm{C}$. For short duration storage of $4-5$ days, the bacterial cultures were kept at $+4^{\circ} \mathrm{C}$.

Buffalo calf blood experimentally infected with $P$. multocida $\mathrm{B}: 2 \mathrm{P}_{52}$ (Vaccine strain) was obtained from Haryana Veterinary Vaccine Institute (HVVI), Hisar. P. multocida type A (bovine strain) was obtained from Indian Veterinary Research Institute, Izatnagar and was maintained and cultured. Anti-mouse HRPO conjugate raised in rabbit was purchased from Sigma Aldrich Co., (cat. No.9044) and referred as "The Conjugate". Anti-pasteurella multocida monoclonal antibody referred as "HS-1 Mab" was produced in the department during the doctoral research of Pankaj Kumar (2014) by the hybridoma secreting the monoclonal antibody and raised in vivo in ascites fluid of mice, anti- pasteurella multocida whole bacterial cell hyper immune serum named as "The coating antibody" and raised in rabbit. P. multocida type B specific PCR primers KTSP61 and KTT72 were commercially synthesized from Sigma-Aldrich Chemical Pvt. Ltd., Bangalore, India.

\section{Experimental animals}

Male Swiss albino mice aged 8-10 weeks were procured from Disease Free Small Animal House, Lala Lajpat Rai University of Veterinary \& Animal Sciences, Hisar. The mice were caged, fed ad libidum and used within 2 days of procurement. Approval of Institutional Animal Ethics Committee for animal experimentation was granted vide VPHE/IAEC/88-108 dated 19/04/2014.

Development and optimization of monoclonal antibody sandwich ELISA for diagnosis of hemorrhagic septicemia

A monoclonal antibody based sandwich ELISA was developed and optimized as per the guidelines of OIE (2012) for assay development. The test was standardized for: determination of optimum dilutions of the bioreagents, repeatability, estimation of cutoff, analytical sensitivity and specificity and normalization of data. The test was developed to the extent that it could become fit for clinical diagnosis of experimentally produced HS in mice. Stocks of $P$. multocida $\mathrm{B}: 2$ and $P$. multocida type A were raised and their Purity, identity was done by using various biochemical tests viz. Catalase test, Oxidase 
test, Indole test, and confirmation was done by using PCR with KTSP61:5'- ATC-CGCTAA-CAC-ACT-CTC-3 ${ }^{\prime} \quad\left(\mathrm{Tm}=55.0^{\circ} \mathrm{C}\right) \quad(\mathrm{F})$ and KTT72: 5'-AGG-CTC-GTT-TGGATT-ATG-AAG-3 ${ }^{\prime} \quad\left(\mathrm{Tm}=61.9^{\circ} \mathrm{C}\right)$ primers.

\section{Preparation of bacterial antigens}

Whole killed bacterial cells antigen, sonicated antigen and LPS antigen were prepared. The $P$. multocida B:2 BHI broth was formaldehyde treated. A $37 \%$ formaldehyde solution was added to achieve $0.5 \%$ concentration of formaldehyde in The $P$. multocida B:2 BHI broth. A small volume of $5 \mathrm{ml}$ was saved for estimation of colony forming units (cfu). It was stored at $+4{ }^{\mathrm{O}} \mathrm{C}$ overnight and used next day for estimation of cfu.

\section{The whole killed bacterial cell antigen}

Of the $195 \mathrm{ml}$ The P. multocida B:2 BHI broth of inactivated bacteria, approximately $50 \mathrm{ml}$ broth was used. It was pelleted by centrifugation at $3000 \mathrm{rpm}$ (swing out rotor, Remi centrifuge model no R-4CDx Laboratory centrifuge). Supernatant was discarded and bacterial pellet was suspended in $20 \mathrm{ml}$ phosphate buffer saline (PBS-T). It was stored at $+4^{\circ} \mathrm{C}$ till use.

\section{Estimation of colony forming units}

Limiting dilution method was used (Prescott et al., 2002). The dilution that produced about 20-30 bacterial colonies on the Petri plate was considered for estimation of $\mathrm{cfu}$ in The P. multocida B:2 BHI broth.

\section{The sonicated bacterial antigen}

Approximately $100 \mathrm{ml}$ of The $P$. multocida B:2 BHI broth was centrifuged as described above. Supernatant was discarded and pellet was suspended in about $30 \mathrm{ml}$ PBS-T. The bacterial cells were disrupted by ultra sonication (ultra sonication model ultrasonicator-Micronix S-4000 micronix) as per standard procedure and the supernatant was saved and stored at $-20^{\circ} \mathrm{C}$ till use. This way sonicated bacterial antigen was prepared.

\section{Estimation of protein concentration of} sonicated antigen

Estimation of protein concentration of sonicated antigen was done as per the method described by Bradford (1976) by using Coomassie Blue G-250. The absorbance of the sample at $595 \mathrm{~nm}$ was taken and the protein concentration was determined from the standard curve.

\section{The LPS antigen}

Bacterial LPS antigen was prepared as described by Pandian et al., (1999). A total of $45 \mathrm{ml}$ of The P. multocida B:2 BHI broth was used for preparation of LPS antigen.

\section{Estimation of carbohydrate concentration of LPS antigen}

The amount of carbohydrate was estimated for determination of analytical sensitivity of The ELISA test of LPS antigen. It was done by sulphuric acid-UV method using the regression equation as described by Albalasmeh et al., (2013).

\section{Assay development and validation}

Sandwich ELISA was developed and optimized. The ELISA plate wells were coated with the coating antibody. The coating antibody captured the antigen. Then antigen was detected by the HS-1 Mab. The binding of the HS-1 Mab with the captured antigen was detected by the conjugate and finally the test was developed with 3,3,5,5, Tetra Methyl 
Benzidine (TMB). The optical density of the colour (OD value) was recorded in an ELISA reader at filter wave length $450 \mathrm{~nm}$. The test was standardized and optimized for all three types of antigens (whole killed bacterial cell antigen, sonicated antigen and the LPS antigen).

For the sandwich ELISA, the wells of a 96 well flat bottom ELISA plate (Maxisorp, Nunc) were coated with $50 \mu 1 /$ well of appropriate dilution of the coating antibody prepared in coating buffer. The plate was covered and kept at $+4^{0} \mathrm{C}$ overnight. Next day, the plate wells were washed with washing buffer (PBS-TT) and then discarded by flick of wrist. This was done $5 \mathrm{X}$.

The wells of the plate were blotted dry. This way washing and drying of the ELISA plate wells were done. Antigen was diluted in diluent and appropriately diluted antigen was added as $50 \mu 1 /$ well. The plate was covered with plate cover and then incubated $35-36^{\circ} \mathrm{C}$ for $1 \mathrm{~h}$. The wells of the plate were again washed and dried as described above. Appropriately diluted HS-1 Mab, was added as 50 $\mu 1 /$ well and ELISA plate incubated as described above. The plate wells were washed as done above and appropriately diluted conjugate was added as $50 \mu 1 /$ well. The plate was again incubated, washed and dried as described above.

To develop the test, TMB solution was added as $50 \mu \mathrm{l} /$ well. The colour was allowed to develop for 7-8 min and then the reaction was stopped by acidification. The stopping solution

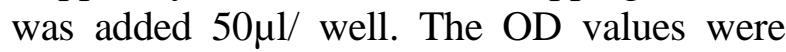
read at $450 \mathrm{~nm}$ wave length. This is described as, "The ELISA test."

In each setup of the ELISA, appropriate control was kept. The controls were set up as blank, negative and positive controls as required in an experiment.

\section{Standardization of the test}

Chequer board titration was performed for standardization of the test. This was done for determination of optimum dilutions of: 1- The coating antibody, 2- HS-1 Mab and 3- The conjugate. The optimum dilutions were determined for 1:5, 1:50 and 1:100 dilutions of antigens.

A 96 well ELISA plate (Nunc) was divided in to four parts. The coating antibody was twofold diluted column-wise (1:125 to $1: 1000,4$ steps) and the conjugate diluted two fold rowwise (1:200 to 1:6400, six steps). A dilution of HS-1 Mab was added to wells of one of four parts of the plate. The dilutions of HS-1 Mab used were 1:500, 1:800, 1:1000 and 1:1500. Layout of ELISA plate is shown in Figure 11. Combination of the most diluted coating antibody, HS-1 Mab, The conjugate and the antigen in a well showing appreciable colour development (at least, OD 0.2) taken as optimum dilution of The coating antibody, HS-1 Mab and The conjugate.

\section{The repeatability studies}

For testing the robustness of the test, repeatability study was performed. The experiment was set up as described in OIE (2012). However, 24 replicates of each three dilutions of an antigen (1:5, 1:10, 1:50) were kept in the ELISA plate. These way three plates were set up and the experiment was repeated in similar manner on three different days.

\section{Statistical analysis}

Mean and standard deviations (SD) of OD values of the wells: intra-plate, inter-plate and inter-days were calculated in MS Excel 2007. From the values of mean and SD, coefficient of variation $(\mathrm{CV})$ was calculated by dividing $\mathrm{SD}$ over mean $(\mathrm{CV}=\mathrm{SD} /$ mean). The $\mathrm{CV}(\mathrm{s})$ 
were calculated for all the three dilutions of all the three antigens.

\section{Estimation of cut off value}

Cut off value is determined to establish criterion for declaring a test positive or negative. In the study, mean $+3 \mathrm{SD}$ of OD value negative control wells were taken as cut off value. The ELISA was set up with two different types of negative control wells. In one type of negative control wells, only diluent was added and no antigen was added. In the second type of negative control wells, an antigen of $P$. multocida $\mathrm{B}: 2$ was added but an ascites fluid containing unrelated monoclonal antibody was used. The ELISA test was performed with all three types of the P. multocida B:2 antigens. The ELISA test conditions were kept same as standardized for a type of $P$. multocida B:2 antigen. For the ascites of unrelated monoclonal antibody, the dilution of the ascites fluid was kept similar to the dilution of HS-1 Mab for that type of $P$. multocida $\mathrm{B}: 2$ antigen.

\section{Analytical sensitivity}

Analytical sensitivity is the lowest amount of analyte that can be detected by the test. For estimation of analytical sensitivity of The ELISA standardized for all three types of antigens. The ELISA test was performed with two fold serial dilutions of an antigen (12 steps and in triplicate) but for whole killed bacterial cell antigen it was performed in the ELISA well module (8X2). The highest dilution of antigen recorded OD value equal to the cut off value was taken as the ELISA titre. The dilution of the ELISA titre was used to estimate the amount of an antigen in that dilution. The amount of antigen in stock of whole killed bacterial cell, sonicated and the LPS were estimated as described in sections 3.6.2.1a, 3.6.2.2a, 3.6.2.3a respectively. Amount of antigen in stock was divided by the dilution of the ELISA titre to calculate amount of antigen in $50 \mu 1$ volume of the antigen dilution. This way analytical sensitivity of the ELISA for all three types of antigen was established.

\section{Analytical specificity}

Analytical specificity is the degree to which the assay does not cross react with other analyte. Analytical specificity of The ELISA test was established against $P$. multocida type $A$ antigen of bovine strain and the ELISA test was performed with a change that $P$. multocida type A antigen was used in place of P. multocida B:2 antigen. The ELISA was done with all three types of the antigens (whole bacterial cell killed, sonicated and the LPS antigen of $P$. multocida type A). The ELISA test conditions were kept same as standardized for $P$. multocida $\mathrm{B}: 2$ antigens. For a type of antigen, all optimum dilutions of The coating antibody, HS-1 Mab and The conjugate were kept same as standardized for that type of $P$. multocida B:2 antigen. The whole killed bacterial cell antigen was used as undiluted stock of the bacterial culture while sonicated and the LPS antigen was used in dilution 1:5. Though, amount of protein in sonicated antigen, and carbohydrate in the LPS antigen of $P$. multocida type A culture broth were not estimated but the number of cfu were estimated and the dilution of the stock culture in BHI broth was so adjusted that the number of $\mathrm{cfu}$ in the BHI broth of both $P$. multocida B:2 and P. multocida type A became similar in number. This was done to have amount of protein in sonicated antigen and carbohydrate in LPS almost similar to the antigen of $P$. multocida B:2. The number of cfu in stock culture of $P$. multocida type A were higher than that in stock culture of $P$. multocida B:2. The stock culture of $P$. multocida type A was, therefore, appropriately diluted and then the whole killed bacterial cell, sonicated and the LPS 
antigens of $P$. multocida type A were prepared respectively, for $P$. multocida $\mathrm{B}: 2$. Four replicates of a type of the antigen of $P$. multocida type A were tested together positive control. In positive control, another anti-pasteurella multocida monoclonal antibody that cross reacts equally with $P$. multocida B:2 and $P$. multocida type A (Pankaj Kumar,2014) was used. The dilution of the cross reacting monoclonal antibody was kept similar to the dilution of HS-1 Mab standardized for a type of antigen.

\section{Normalization of data}

To minimize test to test variations, normalization of the data was done. The OD value of test well could either be converted as percentage of reaction in comparison to $\mathrm{OD}$ value of known positive control or it could be expressed as ratio of test well OD value over negative control well OD value. In the study, ratio of test well OD over mean $+3 \mathrm{SD}$ value of negative control wells OD was used for normalization of data.

\section{Evaluation of the test for clinical diagnosis of HS}

The ELISA test standardized and optimized with laboratory prepared $P$. multocida B:2 antigens was assessed for its fitness as test for clinical diagnosis of the disease. The test was evaluated not only for its fitness for clinical diagnosis of HS but also its capacity to diagnose the disease at an early stage, before the appearance of clinical symptoms. The bacteria could be in any of the three forms i.e. whole bacterial cell, disintegrated bacterial cell and LPS. The sonication mimicked the disintegration of the bacterial cell. While, whole bacterial cell is expected in the early stages of the disease, protein and LPS antigens of disintegrated bacteria are likely to be present in samples collected from animals with clinical symptoms or died of HS. The
ELISA test was developed for all three types of antigens but the ELISA test developed for whole killed bacterial cell was used. This was done to assess the capacity of The ELISA test for early diagnosis of HS.

A total of 9 mice were experimentally infected with $P$. multocida $\mathrm{B}: 2$ P52 strain by $\mathrm{s} / \mathrm{c}$ inoculation of $0.5 \mathrm{ml} \mathrm{BHI}$ broth containing $100 \mathrm{cfu}$. One mouse was kept as non-infected control. The control mouse received $0.5 \mathrm{ml}$ BHI broth without $P$. multocida B:2.

The heart blood of the infected mice was collected at 2, 4, 8, 12 and $24 \mathrm{~h}$ post infections. The surviving mice were killed by cervical dislocation and heart blood was collected directly by puncturing the heart. Two mice were used at each sampling except. The heart blood of the non-infected mouse was collected at the time of sampling at $24 \mathrm{~h}$ post infection.

\section{Isolation of bacteria from clinical samples}

The Isolation of bacteria, ELISA test and PCR were performed on the collected blood samples. The control mouse was killed by cervical dislocation. The blood samples at various time post infections were tested by The ELISA test as standardized for whole killed bacterial cell was setup. The ELISA test results were compared with "Gold standard' of HS diagnosis. The heart blood samples of various time post infections were tested for isolation of bacteria and for the detection of the bacterial DNA by PCR. Heart blood of individual infected mouse, at various sampling, was streaked on a $35 \mathrm{~mm} \mathrm{5 \%} \mathrm{sheep}$ blood agar Petri plate for isolation of the bacteria and the heart blood of two mice at a sampling time was pooled and then used for detection of the target bacterial DNA by PCR. The pooled blood samples were also used in The ELISA test. 


\section{The ELISA test}

The ELISA test was performed with the optimum dilutions 1:1000, 1:500 and 1:800 for the coating antibody, HS-1 Mab and The conjugate, respectively. Two dilutions of the blood samples (Undiluted and 1:2 diluted) were tested. The heart blood collected at all the sampling time, was hemolysed by adding distilled water three times. This was done to remove any interference of red blood cells in antigen binding. Approximately $100 \mu 1$ of blood could be collected from each mouse and it could be suitably hemolysed with distilled water resulting in to1:3 dilution of the blood. This 1:3 diluted blood sample was used as undiluted blood sample. The mice at $24 \mathrm{~h}$ post infection died much before the time of sampling (during very early hours of morning). Very little amount of heart blood could be collected. As such there was no blood sample, therefore heart was cut and little heart blood samples whatever amount, could be collected by washing the thoracic cavity with $0.3 \mathrm{ml}$ distilled water. The prior dilution of this heart blood sample of $24 \mathrm{~h}$ in undiluted blood, could not be determined. The samples appeared to be highly diluted (Fig. 1 and 2). The layout of ELISA well module is shown in Figure 11 and OD values of heart blood samples are shown in Table 1.

\section{The PCR}

The PCR was performed on undiluted as well as diluted blood samples (Table 2). The $P$. multocida gene specific PCR performed on direct blood samples showed positive amplification in the samples collected 4 and $8 \mathrm{~h}$ post infection. No amplification was recorded for heart blood sample of 12 and $24 \mathrm{~h}$ post infection.

\section{Detection of target DNA in infected mice blood by PCR}

$P$. multocida gene specific, as well as duplex PCR for amplification of $P$. multocida type and $P$. multocida $\mathrm{B}: 2$ were set up. $P$. multocida, serogroups B and type B:2 specific multiplex-PCR was used to confirm the strains as $P$. multocida type B:2. Different sets of primers specific to capsule as well as 16s RNA were used as mention in the (Table $3)$.

\section{PCR parameters}

Three PCR were performed i.e simplex, duplex and multiplex. Simplex PCR using KMT1T7 and KMT1SP6 set of primer specific to $P$. multocida, duplex PCR for simultaneous detection of $P$. multocida Type $B$ using two sets of primer i.e. KMT1T7/KMT1SP6 and KT SP61 /KTT72 however, multiplex PCR using three sets of primer for simultaneous detection of $P$. multocida Type B:2 were used.

The PCR was performed in a thermocycler (Veriti, Invitrogen) with a total reaction volume of $25 \mu \mathrm{L}$ using KAPA blood PCR kit (KK7003).

\section{Results and Discussion}

\section{Culture of $\boldsymbol{P}$. multocida}

The bacteria were streaked on 5\% sheep blood agar Petri plate. Characteristic translucent dew drop like colonies appeared after incubating overnight at $35-36^{\circ} \mathrm{C}$. Gram's staining of the bacterial smear showed Gram negative small cocco-bacilli appearance. Presence of only gram negative small coccobacilli bacteria in the smear, indicated purity of the culture (Fig. 3).

$P$. multocida was identified by various biochemical tests (Table 3) and P. multocida type B was confirmed by PCR. The PCR showed amplification of target DNA (Fig. 4) showing a band of amplicon size of $\sim 620$ base pairs (bp). 


\section{Preparation of bacterial antigens}

No bacterial growth was observed, after overnight incubation of $P$. multocida B:2 broth.

\section{Estimation of colony forming units}

The number of colonies on the Petri plate was 30,24 and 27, inoculated with dilution $10^{-12}$ of the broth of bacterial culture (Fig. 5) and therefore the Petri plates of $10^{-12}$ gave an average of 27 bacterial colonies.

The BHI broth of the bacterial culture contained $27 \times 10^{-12} \mathrm{cfu}$ in $50 \mu 1$ or $54 \times 10^{-13}$ cfu per $\mathrm{ml}$ of The P. multocida type B:2 BHI broth.

This was expected to be an accurate estimation of the bacterial antigen because the bacterial culture was terminated at $8 \mathrm{~h}$, during $\log$ phase of the bacterial growth. In over grown bacterial culture, the culture might contain dead bacterial cell and cfu may not be the correct estimation of whole cell bacterial number.

Estimation of protein concentration of sonicated antigen

The standard curve (Fig. 6) was made using bovine serum albumin with concentrations of $0,10,20,30,40,50 \mu \mathrm{g} / \mathrm{ml}$ for the microassay (extinction coefficient of BSA is 0.667). Protein concentration of sonicated antigen was estimated from standard curve with absorbance at $595 \mathrm{~nm}$. It was estimated to be $44 \mu \mathrm{g} / \mathrm{ml}$.

\section{Estimation of carbohydrate concentration of LPS antigen}

The stock concentration of LPS antigen estimated by sulphuric acid-UV method was $1.392 \mathrm{~g} / \mathrm{ml}$.

\section{Assay development and validation}

Sandwich ELISA was standardized for all three types of antigens by performing Chequer board titration to determine the optimum dilutions of: 1-The coating antibody, 2-HS-1 Mab and 3-The conjugate. The optimum dilutions of antigens were taken as 1:5, 1:50 and 1:100.

\section{Chequer board titration for whole killed bacterial cell antigen}

Raw OD values recorded for antigen concentration 1:5, 1:50 and 1:100 in Chequer board titrations are shown in (Tables 4,5 and $6)$, respectively.

The ELISA plate OD values for antigen dilution 1:50 were used for determination of optimum dilutions. The Optimum dilutions of bio-reagent were selected as the coating antibody- 1:1000, HS-1 Mab-1:500 and the conjugate-1:800.

\section{Chequer board titration for sonicated antigen}

Raw OD values recorded in Chequer board titrations for antigen concentration 1:5, 1:50 and 1:100 are shown in (Tables 7, 8 and 9), respectively. The ELISA plate OD values for antigen dilution 1:100 were used for determination of optimum dilutions. The Optimum dilutions of reagent were selected as: The coating antibody- 1:1000, HS-1 Mab1:1500 and the conjugate-1:6400.

\section{Chequer board titration for LPS antigen}

Raw OD values recorded for antigen concentration 1:5, 1:50 and 1:100 are shown in (Tables 10, 11 and 12), respectively.

The ELISA plate OD values for antigen dilution 1:5 were used for determination of 
optimum dilutions. The Optimum dilutions of reagent were selected as: The coating antibody- 1:1000, HS-1 Mab-1:1500 and the conjugate-1:3200.

\section{Repeatability study}

Three plates on three days with 24 replicates of one antigen dilution in one plate were set up. Repeatability of the test was estimated from calculation of coefficient of variation (CV) from OD values. The experiments were performed for all three types of antigens and the values of estimated CV are given in (Tables. 13, 14, 15) for whole killed bacterial cell, sonicated and LPS antigens, respectively. The CV estimated for intra-plate, inter plate and inter days for all three antigens were largely within $20 \%$. For some ELISA plate, the values of CV was slightly above than $20 \%$ but below $21 \%$. This was due to rounding off values during calculation. However, $23 \%$ and as high as $25 \%$ was recorded for whole killed bacterial cell antigen only.

\section{Estimation of cut off value}

Cut off values were estimated for declaring positive or negative result. The mean $+3 \mathrm{SD}$ values calculated for all three types of antigen and for both formats of negative control wells, are given in (Table 16). The cut off value for whole killed bacterial cell, sonicated and LPS antigens were found to be 0.11 , 0.086 and 0.1 , respectively.

\section{Analytical sensitivity}

The ELISA was performed with various two fold dilutions of an antigen. The highest dilution of the antigen where OD value equivalent to cut off OD values, was recorded as ELISA titre. The OD values were plotted in MS Excel 2007 and exact dilution corresponding to the cut off values was estimated for the ELISA titre (Fig. 7, 8 and 9) for whole killed bacterial cell, sonicated and LPS antigen, respectively.

OD values with whole killed bacterial cell, sonicated and LPS antigens are given in (Tables 17, 18 and 19) respectively. The ELISA titres for whole killed bacterial cell, sonicated and LPS antigen were 1:320, 1:114 and 1:80, respectively. Amount of antigen were: $5.4 \times 10^{14} \mathrm{cfu}$ per $\mathrm{ml}, 44 \mu \mathrm{g}$ per $\mathrm{ml}$ and $1.392 \mathrm{~g}$ per $\mathrm{ml}$ for whole killed bacterial cell, sonicated and LPS antigen, respectively. Therefore, the analytical sensitivity for whole killed bacterial cell was $1.6 \times 10^{11} \mathrm{cfu} / \mathrm{ml}$, $385 \mathrm{ng} / \mathrm{ml}$ for sonicated antigen and $17.4 \mathrm{mg} / \mathrm{ml}$ for LPS antigen.

\section{Analytical specificity}

High OD values in positive control wells and OD values close to zero in wells of $P$. multocida Type A bovine strain (Table 20) established the analytical specificity of the test for $P$. multocida type B against most closely related bacteria.

\section{Standardized ELISA for clinical diagnosis of HS}

The ELISA as standardized above, for whole killed bacteria cell was used for diagnosis of HS in experimentally infected mice. The selected optimum dilutions were 1:1000, 1:500 and 1:800 for the coating antibody, HS$1 \mathrm{Mab}$ and The conjugate, respectively.

\section{Isolation of bacteria from clinical samples for evaluation of the test}

The bacterial growth was observed with 20 colonies in the blood samples taken after $8 \mathrm{~h}$ and 45 colonies $12 \mathrm{~h}$ while no discrete colony was seen in the culture of blood sample of 24 h. The bacteria were identified as $P$. multocida by appearance in Gram's stain smears. 


\section{The ELISA test}

The ELISA test was performed with the optimum dilutions 1:1000, 1:500 and 1:800 for the coating antibody, HS-1 Mab and The conjugate, respectively. Two dilutions of the blood samples (Undiluted and 1:2 diluted) were tested. The layout of ELISA well module is shown in Figure 11 and OD values of heart blood samples are shown in Table 21.

\section{The PCR}

The PCR was performed on undiluted as well as diluted blood samples. The P. multocida gene specific PCR performed on direct blood samples showed positive amplification in the samples collected 4 and $8 \mathrm{~h}$ post infection. No amplification was recorded for heart blood sample of 12 and $24 \mathrm{~h}$ post infection. The PCR for duplex amplification of $P$. multocida $\mathrm{B}$ and serotype B:2 specific gene performed on blood samples showed positive amplification in samples collected 4,8 and $12 \mathrm{~h}$ post infection but the lane no.7 of (Fig. 10) for samples collected $24 \mathrm{~h}$ post infection showed smearing. This indicated high amount of template bacterial DNA in the sample of $24 \mathrm{~h}$ post infection.

The blood sample of $24 \mathrm{~h}$ post infection was further three fold diluted to lower the amount of template DNA and then PCR for duplex amplification of $P$. multocida $\mathrm{B}$ and serotype $\mathrm{B}: 2$ specific gene was performed. Positive amplification could be noted in samples collected 8, 12 and $24 \mathrm{~h}$ post infection. The sample of 8 and $12 \mathrm{~h}$ post infection showed amplification for both $P$. multocida B and sero type B:2 specific genes. The samples at $24 \mathrm{~h}$ post infection showed amplification of only P. multocida serotype B:2 specific gene, lane no.6 of (Fig. 10). The target bacterial DNA, therefore, could be detected in heart blood samples of $4,8,12$, and $24 \mathrm{~h}$ post infection.
Comparative evaluation of bacterial isolation, ELISA and PCR for the samples of experimentally infected mice

The results of isolation of bacteria, The ELISA test and PCR on heart blood samples of experimentally infected mice are given in (Table 20 and 21).

The ELISA recorded positive results even in 2 $\mathrm{h}$ post infection but PCR tested positive in $4 \mathrm{~h}$ sample and bacteria started appearing at $8 \mathrm{~h}$ post infection. The OD values in test wells of infected blood samples demonstrated much higher value when compared with heart blood of non-infected mouse. The OD values in both undiluted and diluted heart blood samples demonstrated an increasing trend from $2 \mathrm{~h}$ onwards to $12 \mathrm{~h}$. However, lower OD values were recorded in samples of $24 \mathrm{~h}$ post infection.

Prompt diagnosis of bacterial infectious diseases of livestock is an important step in management of outbreaks. In many developing or underdeveloped Asian countries, including India, an effective vaccination based control programme is not in place. This is due to poor animal husbandry conditions as a result of lack of facilities, noncooperative attitude of livestock owners due to ignorance and poor knowledge. For diseases that occur on an outbreak scale and an effective vaccine is also available for their successful prevention, even then veterinary health personnel are compelled to adopt approach of treatment of diseased animals with antibiotics. In India, this approach of antibiotics treatment and not prevention of the disease by regular vaccination with wider coverage is a common practice for tackling HS. Per acute nature of the disease results in to very short course of the disease and the fact that antibiotic treatment is disadvantageous at later stage of the disease, there is very little time available with veterinarians to start the 
treatment of diseased animals with antibiotics. Treatment with antibiotics is of limited value unless carried out in the very early stages (Buxton and Fraser, 1977). Huge economic losses, predominantly, due to death of young adult buffaloes creates a panic and often antibiotic treatment is started without confirmation of the disease. The indiscriminate use of antibiotics leads to emergence of resistance in bacteria, undue contamination of the environment and the life of the animal is also not saved and money of livestock owner is wasted on purchase of expensive antibiotics. It is therefore demand of time that, sensitive, specific, point-of care and affordable diagnostics should be available to veterinarians.

Importance of diagnostics led to focus of researchers on developing newer and better diagnostics. This resulted in to rapid advancement in techniques and technology of disease diagnosis.

In the present study, a monoclonal antibody based sandwich ELISA was developed for HS. An anti-pasteurella multocida B:2 strain $\mathrm{P}_{52}$ (vaccine strain) whole bacterial cell polyclonal serum was used as capture antibody. The immune response to whole bacterial cell involved the activation of multiple B-cell which target a specific epitope on the bacterial cell. As a result, a large number of antibodies were produced with different specificities and epitope affinities. In contrast, monoclonal antibodies are antibodies produced by a single B lymphocyte clone. As most monoclonal antibodies lose some or all of their binding affinity when adsorbed on plastic, there is an advantage in coating with polyclonal antibodies because at least some of the population of antibodies retain binding activity when adsorbed (Wild and Kusnezow, 2005). Considering the advantages of polyclonal serum as capture antibody, the anti- pasteurella whole bacterial cell polyclonal serum was used as capture antibody and the HS-1 Mab was used as tracing antibody. Though, the polyclonal serum would capture $P$. multocida or other bacterial antigen close to the $P$. multocida, however, specificity of the test would be maintained. The tracing monoclonal antibody, being $P$. multocida $\mathrm{B}$ specific, would bind only to captured $P$. multocida type B.

The objective of the research was not only to develop a specific ELISA for HS but the test should have the capacity for early diagnosis of the disease. For this reason, the standardized ELISA was applied on samples collected at different hours post infection of experimentally infected mice. The blood samples of as early as $2 \mathrm{~h}$ post infection were tested for presence of the bacterial antigen. The clinical manifestations of the typical HS disease caused by B:2 or E:2 strains include a rise in temperature, respiratory distress with nasal discharge, and frothing from the mouth, leading to recumbency and death. Septicemia is the characteristic feature in all the disease conditions. The incubation period varies from 3 to 5 days. In peracute cases, sudden death with observable clinical signs may be observed (Carter and De Alwis, 1989) and De Alwis (1992b). Characteristic of sudden onset of disease leading to rapid death of infected animals is similar to that seen in other clinical conditions known to involve endotoxic shock (Radostits et al., 2007). Horadagoda et al., (2001) studied role of endotoxin in the pathogenesis of hemorrhagic septicemia in buffaloes. The findings demonstrated that a progressive endotoxaemia and associated sequel, correlates with the development of overt hemorrhagic septicemia disease and sudden death in buffaloes. It was, therefore, expected that the antigens of three types i.e. whole bacterial cells, disintegrated bacterial cells due to death of bacteria and the LPS released from the dead bacterial cells are likely to be present in the clinical sample. In 
view of this, ELISA was standardized for whole killed bacterial cells, sonicated bacterial cells antigen and the LPS antigen.

During the standardization of ELISA, it was observed that The ELISA test, with sonicated antigen performed better than whole killed bacterial cell and the LPS antigen because, for sonicated antigen, the ELISA plate OD values for antigen dilution 1:100 were used for determination of optimum dilutions. The optimum dilutions of reagent were selected as: The coating antibody- 1:1000, HS-1 Mab$1: 1500$ and the conjugate- $1: 6400$. Though, for the LPS antigen, higher optimum dilutions of bio-reagents: The coating antibody-1:1000, HS-1Mab-1:1500 and The conjugate-1:3200 were selected but, the test for LPS could be performed with 1:5 dilutions of antigen only and the OD value of selected well was also 0.206 , just reaching to the minimum acceptable OD value as describe in section 3.6.3.1. For sonicated antigen, the selected antigen dilution was 1:100 and the OD value of the selected well was 0.840 , much higher than the OD value of 0.206 for LPS antigen. The physical form of the antigen influences how one detects its reaction with an antibody. If the antigen is a particulate, one generally looks for agglutination of the antigen by the antibody. If the antigen is soluble one generally looks for the precipitation of the antigen after the production of large insoluble antigen-antibody complexes (Mayer, 2013). Lower performance of the test for whole killed bacterial cell antigen was, therefore, due to physical form of the antigen and the soluble form of antigens in sonicated and the LPS antigen preparations performed better. The ELISA test could perform only in lower dilution of the LPS antigen (1:5 dilution). This was, perhaps, due to lower amount of the antigen in the LPS antigen preparations. The epitope of the HS-1 Mab has been reported to be present on fimbriae (Pankaj Kumar, 2014). Extraction of LPS from bacterial cells would have been satisfactory, but the epitope of the HS-1 Mab is not present on LPS or outer membrane proteins co-extracted with LPS. Purified LPS of $P$. multocida has been reported to be non protective and it was concluded that LPS preparation contaminated with outer membrane protein could afford protection (Muniandy and Mukkur, 1993). It appeared that, some amount of fimbrial antigen was co-extracted with the LPS. Being a soluble antigen, it could perform better in ELISA and therefore, higher optimum dilutions of bio-reagents were selected but being low in amount in LPS antigen preparation, it could work only in lower dilution of the LPS antigen.

The test is considered a repeatable test if CV is within $20 \%$. The ELISA test was found to be a repeatable test with few exceptions when $\mathrm{CV}$ varied more than $20 \%$. For most ELISA test the CV recorded beyond $20 \%$ in decimals only and it was due to rounding off during calculations. In some instances, as high as $23 \%$ and $25 \% \mathrm{CVs}$ were also recorded. However, higher percentages of CVs were not due to higher values of standard deviations but due to lower mean values. The $\mathrm{CV}$ is calculated by dividing SD by mean value. The test could be considered a poorly repeatable test only if value of standard deviation is high.

Analytical sensitivity for whole killed bacterial cell was $1.6 \times 10^{11} \mathrm{cfu} / \mathrm{ml}, 385 \mathrm{ng} / \mathrm{ml}$ for sonicated antigen and $17.4 \mathrm{mg} / \mathrm{ml}$ for LPS antigen. The analytical sensitivity of whole killed bacterial cell and the sonicated antigen are of more relevance for standardization of test as diagnostic test of HS. This is because of the fact that the fimbrial antigens are likely to be present in whole killed bacterial cell and in sonicated antigen preparations.

It has been reported that $1.6 \times 10^{9} \mathrm{cfu}$ Escherichia coli (Tanner, 1948) would weigh a gram and therefore, 385ng of the sonicated 
antigen is likely to be provided by $20 \times 10^{3}$ bacterial cells (320 ng to be exactly). In an experiment of estimation of cfu in experimentally infected buffalo calf blood, $2 \times 10^{7} / 50 \mu 1$ bacterial cells were recorded (Arvind Kumar, Personal communication, 12 March, 2015). Though approximately only $10^{7} \mathrm{cfu} / \mathrm{ml}$ would, likely, be present in blood of diseased animal, the analytical sensitivity of $1.6 \times 10^{11} \mathrm{cfu} / \mathrm{ml}$ for whole killed bacterial cell was not considered to be a lower sensitivity because amount of fimbrial antigen was, perhaps, not a limiting factor but capture of particulate antigen was responsible for lower analytical sensitivity of whole killed bacterial cells.

Finally, the ELISA test standardized for whole killed bacterial cell was selected for testing blood samples of experimentally infected mice. This decision was based on two reasons. Whole bacterial cells were expected to be present in blood samples collected at early hours of post infection and the whole bacterial cell is also present in heart blood of animals died of HS. Much of the bacterial multiplication takes place in the carcass after death (De Alwis, 1999) and therefore number of bacteria would increase many folds in the heart blood of dead animals. Another reason was that it covered optimum dilutions for both sonicated and the LPS antigens.

The mean +3 SD values calculated for all three types of antigen and for both formats of negative control wells, are given in (Table 16). The cut off value for whole killed bacterial cell, sonicated and LPS antigens were found to be $0.11,0.086$ and 0.1 , respectively. A percentage of $99.9 \%$ area of a normal population lies within mean +3SD (Wardlaw, 1985). Only one value for sonicated antigen where no antigen was added to test well, recorded above mean $+3 \mathrm{SD}$. This could have been an outlawed value. The cutoff values were very low. It was recorded maximum 0.11 for whole killed bacterial cell. In fact, the OD values would have been much lower, had a blank well kept and the test well OD values were substracted from the OD values of blank well. Some diffraction of light is recorded due to plastic or otherwise when blank well is read in ELISA reader. Low cutoff values indicated low back ground reactions and therefore specific detection of antigen and antibody reactions in The ELISA test.

The ELISA test recorded very low OD values in test wells of $P$. multocida type A antigens of all three types and HS-1 Mab while high OD values were recorded in positive control well. This established the analytical specificity of the test. The HS-1 Mab detected its epitope present only on P. multocida type B.

In the study on evaluation of the standardized ELISA for diagnosis of HS in experimentally infected mice, there was an agreement in results of bacterial isolation, PCR and The ELISA test for samples collected $8 \mathrm{~h}$ post infections onwards. However, The ELISA tested recorded positive results even in sample collected $2 \mathrm{~h}$ post infection.

The ELISA test was based on a monoclonal antibody that detected its epitope on type IV fimbriae of $P$. multocida type B. Colonization of host tissue by Gram-negative bacteria is facilitated by various adhesins, one of which is type IV fimbriae. These structures have been associated with pathogenesis in several bacterial species, and have been shown to mediate colonization of epithelial surfaces (Doughty et al., 2000). The colonization of host surfaces by bacteria is frequently mediated by adhesions such as fimbriae (pili). Thus, attachment by fimbriae to host surfaces is usually correlated with virulence (Ruffolo et al., 1997). Shivchandra et al., (2013) 
reported $P$. multocida isolates possess type IV fimbriae as one of the major virulence factors based on their role in adhesion to host surfaces and subsequent pathogenesis. Interestingly, existence of absolute homogeneity amongst the $P$. multocida isolates that caused HS in bovines and septicemic pasteurellosis in sheep and goats was noticed. Infection experiments of Actinobacillus pleuropneumoniae with cultured epithelial cells demonstrated that Tfp promoter activity of type IV fimbriae was upregulated upon adherence of the pathogen to primary cultures of lung epithelial cells (Boekema et al., 2004). The positivity of The ELISA test on of $2 \mathrm{~h}$ post infection could have been due to up-regulation of fimbriae and its role in virulence and pathogenesis. Therefore fimbrial antigens could appear in blood even before the presence of bacterial DNA in the blood sample of $4 \mathrm{~h}$ post infection.

Comparative lower OD values of The ELISA test performed with samples of $24 \mathrm{~h}$ post infection were due to over dilution of the sample. It has been mentioned earlier that the mice died before the time of collection and only scanty amount of the sample could be collected and therefore it has to be diluted for use in The ELISA test.

The PCR was performed on undiluted as well as diluted blood samples. The $P$. multocida gene specific PCR performed on direct blood samples showed positive amplification in the samples collected at $8 \mathrm{~h}$ post infection. Failure of appearance of DNA band in the lane for heart blood sample of 12 and $24 \mathrm{~h}$ post infection was found to be due to inappropriate samples (Fig. 10). Scanty amount of blood could be collected from mice found dead at $24 \mathrm{~h}$ post infection and clotting of blood of samples collected at $12 \mathrm{~h}$ post infection caused non availability of enough template DNA for amplification. The PCR for duplex amplification of $P$. multocida $\mathrm{B}$ and serotype B:2 specific gene performed on blood samples showed positive amplification in samples collected at 4,8 and $12 \mathrm{~h}$ post infection but the lane for samples collected at $24 \mathrm{~h}$ post infection showed smearing. This indicated high amount of template bacterial DNA in the sample of 24 hours post infection. High amount of template DNA is one of the reasons for smearing in agarose gel electrophoresis after DNA amplification in PCR (Lorenz, 2012; Roux, 2003). Faint band in lane for sample of $4 \mathrm{~h}$ post infection was due to dilution of template DNA in the sample (Fig. 10).

The blood sample of $24 \mathrm{~h}$ post infection was further three fold diluted to lower the amount of template DNA and then the PCR for duplex amplification of $P$. multocida $\mathrm{B}$ and serotype B:2 specific gene was performed. Positive amplification could be noted in samples collected 8,12 and $24 \mathrm{~h}$ post infection. The sample of 8 and $12 \mathrm{~h}$ post infection showed amplification for both $P$. multocida $\mathrm{B}$ and sero type B:2 specific genes. The samples at $24 \mathrm{~h}$ post infection showed amplification of only $P$. multocida serotype $\mathrm{B}: 2$ specific gene.

Positive amplification for $P$. multocida $\mathrm{B}: 2$ only in the diluted sample of 24 hours post infection, indicated the sensitivity of the test. P. multocida $\mathrm{B}: 2$ specific gene amplification was more sensitive than $P$. multocida gene and $P$. multocida $\mathrm{B}$ specific gene in PCR due to smaller size of amplicon. The amplicon size for $P$. multocida $\mathrm{B}: 2$ specific gene was 334 basepairs and amplicon size for $P$. multocida gene and $P$. multocida $\mathrm{B}$ specific gene was 460 and 620 basepairs. Size of amplicon is directly related to performance of PCR. Shorter size of amplicons is generally preferred over larger sized amplicons. The processivity of Taq DNA polymerase is low because it lacks proof-reading ability. 
Table.1 OD values of The ELISA performed for testing heart blood samples of experimentally infected mice

\begin{tabular}{|c|c|c|c|c|}
\hline & $\mathbf{1}$ & $\mathbf{2}$ & $\mathbf{3}$ & $\mathbf{4}$ \\
\hline $\mathbf{A}$ & 0.12 & 0.12 & 1.559 & 1.637 \\
\hline $\mathbf{B}$ & 1.450 & 1.362 & 1.085 & 1.088 \\
\hline $\mathbf{C}$ & 0.768 & 0.754 & 0.457 & 0.512 \\
\hline $\mathbf{D}$ & 1.332 & 1.334 & 0.288 & 0.343 \\
\hline $\mathbf{E}$ & 0.802 & 0.882 & -0.043 & -0.042 \\
\hline $\mathbf{F}$ & 1.486 & 1.360 & -0.014 & 0.011 \\
\hline $\mathbf{G}$ & 1.118 & 1.143 & & \\
\hline $\mathbf{H}$ & 1.413 & 1.435 & 1.300 & 1.424 \\
\hline
\end{tabular}

Table.2 List of primers used in PCR

\begin{tabular}{|c|c|c|c|}
\hline Primer Name & Sequences(5'-3') & Product size & \\
\hline KMT1T7 & ATC CGC TAT TTA CCC AGT GG & \multirow[t]{2}{*}{ 460bp } & \multirow[t]{4}{*}{ Townsend et al. (1998) } \\
\hline KMT1SP6 & GCT GTAAAC GAA CTC GCC & & \\
\hline KT SP61 & ATC CGC TAA CAC ACT CTC & \multirow[t]{2}{*}{$\sim 620 \mathrm{bp}$} & \\
\hline KTT72 & AGG CTC GTT TGG ATT ATG AAG & & \\
\hline IP-F & CGA AAG AAA CCC AAG GCG AA & \multirow[t]{2}{*}{$334 b p$} & \multirow[t]{2}{*}{ Brickell et al. (1998) } \\
\hline IP-R & ACA ATC GAA TAA CCG TGA GAC & & \\
\hline
\end{tabular}

Table.3 Biochemical tests for identification of $P$. multocida

\begin{tabular}{|l|c|}
\hline Biochemical Tests & Result \\
\hline Indole (red colour indicates positive test) & +ve \\
\hline Oxidase (blue colour indicates positive test) & $+\mathrm{ve}$ \\
\hline Nitrate (red colour indicates positive test) & $+\mathrm{ve}$ \\
\hline Glucose fermentation (yellow colour indicates positive test) & $+\mathrm{ve}$ \\
\hline Sucrose fermentation (yellow colour indicates positive test) & $+\mathrm{ve}$ \\
\hline
\end{tabular}

Table. 4 Chequer board titration for whole killed bacterial cell antigen: 1:5 antigen dilution

\begin{tabular}{|c|c|c|c|c|c|c|c|c|c|c|c|c|}
\hline & $\mathbf{1}$ & $\mathbf{2}$ & $\mathbf{3}$ & $\mathbf{4}$ & $\mathbf{5}$ & $\mathbf{6}$ & $\mathbf{7}$ & $\mathbf{8}$ & $\mathbf{9}$ & $\mathbf{1 0}$ & $\mathbf{1 1}$ & $\mathbf{1 2}$ \\
\hline $\mathbf{A}$ & 0.613 & 0.174 & 0.145 & 0.078 & 0.053 & 0.035 & 0.381 & 0.195 & 0.079 & 0.067 & 0.044 & 0.047 \\
\hline $\mathbf{B}$ & 0.714 & 0.372 & 0.197 & 0.124 & 0.055 & 0.043 & 0.692 & 0.291 & 0.136 & 0.115 & 0.062 & 0.054 \\
\hline $\mathbf{C}$ & 0.672 & 0.412 & 0.202 & 0.123 & 0.067 & 0.057 & 0.418 & 0.242 & 0.105 & 0.075 & 0.058 & 0.069 \\
\hline $\mathbf{D}$ & 0.594 & 0.305 & 0.164 & 0.086 & 0.066 & 0.052 & 0.377 & 0.254 & 0.133 & 0.069 & 0.071 & 0.060 \\
\hline $\mathbf{E}$ & 0.465 & 0.127 & 0.072 & 0.047 & 0.058 & 0.044 & 0.522 & 0.203 & 0.092 & 0.052 & 0.055 & 0.073 \\
\hline F & 0.755 & 0.225 & 0.154 & 0.057 & 0.054 & 0.043 & 0.437 & 0.195 & 0.096 & 0.065 & 0.051 & 0.058 \\
\hline $\mathbf{G}$ & 0.808 & 0.245 & 0.116 & 0.074 & 0.048 & 0.043 & 0.411 & 0.151 & 0.084 & 0.044 & 0.038 & 0.048 \\
\hline H & 0.883 & 0.207 & 0.090 & 0.076 & 0.069 & 0.038 & 0.313 & 0.130 & 0.072 & 0.057 & 0.038 & 0.46 \\
\hline
\end{tabular}


Int.J.Curr.Microbiol.App.Sci (2019) 8(5): 1111-1139

Table.5 Chequer board titration for whole killed bacterial cell antigen: 1:50 antigen dilution

\begin{tabular}{|c|c|c|c|c|c|c|c|c|c|c|c|c|}
\hline & $\mathbf{1}$ & $\mathbf{2}$ & $\mathbf{3}$ & $\mathbf{4}$ & $\mathbf{5}$ & $\mathbf{6}$ & $\mathbf{7}$ & $\mathbf{8}$ & $\mathbf{9}$ & $\mathbf{1 0}$ & $\mathbf{1 1}$ & $\mathbf{1 2}$ \\
\hline $\mathbf{A}$ & 1.110 & 0.564 & 0.443 & 0.208 & 0.159 & 0.060 & 0.572 & 0.255 & 0.143 & 0.101 & 0.096 & 0.058 \\
\hline $\mathbf{B}$ & 1.057 & 0.556 & 0.491 & 0.122 & 0.078 & 0.046 & 0.522 & 0.295 & 0.201 & 0.099 & 0.094 & 0.085 \\
\hline C & 0.661 & 0.304 & 0.279 & 0.089 & 0.055 & 0.052 & 0.329 & 0.164 & 0.108 & 0.058 & 0.052 & 0.100 \\
\hline D & 0.575 & 0.224 & $\mathbf{0 . 2 0 4}$ & 0.080 & 0.049 & 0.043 & 0.295 & 0.143 & 0.090 & 0.049 & 0.035 & 0.061 \\
\hline E & 0.686 & 0.267 & 0.147 & 0.075 & 0.040 & 0.035 & 0.256 & 0.148 & 0.089 & 0.044 & 0.042 & 0.053 \\
\hline F & 0.722 & 0.305 & 0.168 & 0.069 & 0.036 & 0.032 & 0.253 & 0.125 & 0.063 & 0.049 & 0.047 & 0.048 \\
\hline G & 0.407 & 0.157 & 0.070 & 0.037 & 0.034 & 0.033 & 0.240 & 0.098 & 0.053 & 0.048 & 0.046 & .048 \\
\hline H & 0.459 & 0.181 & 0.090 & 0.041 & 0.042 & 0.031 & 0.267 & 0.087 & 0.063 & 0.043 & 0.037 & 0.040 \\
\hline
\end{tabular}

The selected OD value is shown in bold font.

Table.6 Chequer board titration for whole killed bacterial cell antigen: 1:100 antigen dilution

\begin{tabular}{|c|c|c|c|c|c|c|c|c|c|c|c|c|}
\hline & $\mathbf{1}$ & $\mathbf{2}$ & $\mathbf{3}$ & $\mathbf{4}$ & $\mathbf{5}$ & $\mathbf{6}$ & $\mathbf{7}$ & $\mathbf{8}$ & $\mathbf{9}$ & $\mathbf{1 0}$ & $\mathbf{1 1}$ & $\mathbf{1 2}$ \\
\hline $\mathbf{A}$ & 0.668 & 0.277 & 0.169 & 0.115 & 0.079 & 0.090 & 0.592 & 0.268 & 0.160 & 0.095 & 0.065 & 0.082 \\
\hline $\mathbf{B}$ & 0.746 & 0.306 & 0.174 & 0.111 & 0.056 & 0.048 & 0.566 & 0.279 & 0.170 & 0.112 & 0.078 & 0.066 \\
\hline C & 0.523 & 0.206 & 0.103 & 0.071 & 0.041 & 0.035 & 0.387 & 0.183 & 0.104 & 0.083 & 0.066 & 0.061 \\
\hline D & 0.534 & 0.209 & 0.087 & 0.065 & 0.042 & 0.035 & 0.390 & 0.140 & 0.077 & 0.069 & 0.051 & 0.058 \\
\hline E & 0.565 & 0.202 & 0.119 & 0.083 & 0.049 & 0.045 & 0.285 & 0.135 & 0.077 & 0.046 & 0.057 & 0.060 \\
\hline F & 0.524 & 0.193 & 0.099 & 0.057 & 0.047 & 0.036 & 0.274 & 0.135 & 0.059 & 0.040 & 0.041 & 0.034 \\
\hline $\mathbf{G}$ & 0.527 & 0.176 & 0.074 & 0.047 & 0.040 & 0.038 & 0.259 & 0.108 & 0.042 & 0.043 & 0.037 & 0.073 \\
\hline H & 0.493 & 0.175 & 0.071 & 0.049 & 0.039 & 0.035 & 0.329 & 0.147 & 0.044 & 0.038 & 0.040 & 0.048 \\
\hline
\end{tabular}

Table.7 Chequer board titration for sonicated antigen: 1:5 antigen dilution

\begin{tabular}{|c|c|c|c|c|c|c|c|c|c|c|c|c|}
\hline & $\mathbf{1}$ & $\mathbf{2}$ & $\mathbf{3}$ & $\mathbf{4}$ & $\mathbf{5}$ & $\mathbf{6}$ & $\mathbf{7}$ & $\mathbf{8}$ & $\mathbf{9}$ & $\mathbf{1 0}$ & $\mathbf{1 1}$ & $\mathbf{1 2}$ \\
\hline $\mathbf{A}$ & 1.307 & 0.391 & 0.458 & 0.319 & 0.425 & 0.234 & 1.553 & 0.423 & 0.736 & 0.517 & 0.423 & 0.298 \\
\hline $\mathbf{B}$ & 1.677 & 1.293 & 1.114 & 0.813 & 0.601 & 0.375 & 1.463 & 0.859 & 0.855 & 0.625 & 0.428 & 0.430 \\
\hline $\mathbf{C}$ & 1.367 & 0.874 & 0.762 & 0.565 & 0.347 & 0.378 & 1.350 & 0.830 & 0.890 & 0.610 & 0.456 & 0.316 \\
\hline $\mathbf{D}$ & 1.592 & 1.100 & 0.895 & 0.643 & 0.306 & 0.411 & 1.785 & 1.100 & 0.941 & 0.707 & 0.517 & 0.431 \\
\hline $\mathbf{E}$ & 1.462 & 0.750 & 0.437 & 0.352 & 0.262 & 0.392 & 1.193 & 1.018 & 0.725 & 0.545 & 0.131 & 0.265 \\
\hline $\mathbf{F}$ & 1.518 & 0.812 & 0.680 & 0.479 & 0.351 & 0.260 & 1.168 & 0.770 & 0.764 & 0.390 & 0.267 & 0.300 \\
\hline $\mathbf{G}$ & 1.510 & 0.915 & 0.838 & 0.530 & 0.393 & 0.338 & 1.196 & 0.726 & 0.572 & 0.454 & 0.273 & 0.181 \\
\hline $\mathbf{H}$ & 1.389 & 0.913 & 0.809 & 0.587 & 0.418 & 0.307 & 1.138 & 0.772 & 0.611 & 0.449 & 0.300 & 0.121 \\
\hline
\end{tabular}

Table.8 Chequer board titration for sonicated antigen: 1:50 antigen dilution

\begin{tabular}{|c|c|c|c|c|c|c|c|c|c|c|c|c|}
\hline & $\mathbf{1}$ & $\mathbf{2}$ & $\mathbf{3}$ & $\mathbf{4}$ & $\mathbf{5}$ & $\mathbf{6}$ & $\mathbf{7}$ & $\mathbf{8}$ & $\mathbf{9}$ & $\mathbf{1 0}$ & $\mathbf{1 1}$ & $\mathbf{1 2}$ \\
\hline $\mathbf{A}$ & 0.803 & 0.858 & 0.961 & 1.063 & 1.061 & 1.14 & 0.867 & 0.819 & 0.896 & 0.941 & 0.951 & 1.001 \\
\hline $\mathbf{B}$ & 0.8 & 0.623 & 0.887 & 0.981 & 1.048 & 1.081 & 0.714 & 0.678 & 0.799 & 0.88 & 0.935 & 0.954 \\
\hline $\mathbf{C}$ & 0.749 & 0.739 & 0.939 & 1.027 & 1.064 & 1.117 & 0.651 & 0.721 & 0.851 & 0.931 & 0.973 & 0.974 \\
\hline $\mathbf{D}$ & 0.663 & 0.754 & 0.916 & 1.111 & 1.132 & 1.105 & 0.691 & 0.706 & 0.836 & 0.912 & 0.952 & 0.985 \\
\hline $\mathbf{E}$ & 0.707 & 0.797 & 0.88 & 0.934 & 0.948 & 0.933 & 0.642 & 0.742 & 0.817 & 0.832 & 0.844 & 0.85 \\
\hline F & 0.776 & 0.714 & 0.842 & 0.966 & 0.925 & 0.963 & 0.693 & 0.729 & 0.781 & 0.829 & 0.845 & 0.859 \\
\hline $\mathbf{G}$ & 0.687 & 0.719 & 0.851 & 0.932 & 0.929 & 0.961 & 0.616 & 0.708 & 0.801 & 0.832 & 0.847 & 0.848 \\
\hline $\mathbf{H}$ & 0.676 & 0.673 & 0.84 & 0.889 & 0.952 & 0.971 & 0.68 & 0.736 & 0.797 & 0.81 & 0.845 & 0.863 \\
\hline
\end{tabular}


Int.J.Curr.Microbiol.App.Sci (2019) 8(5): 1111-1139

Table.9 Chequer board titration for sonicated antigen: 1:100 antigen dilution

\begin{tabular}{|c|c|c|c|c|c|c|c|c|c|c|c|c|}
\hline & $\mathbf{1}$ & $\mathbf{2}$ & $\mathbf{3}$ & $\mathbf{4}$ & $\mathbf{5}$ & $\mathbf{6}$ & $\mathbf{7}$ & $\mathbf{8}$ & $\mathbf{9}$ & $\mathbf{1 0}$ & $\mathbf{1 1}$ & $\mathbf{1 2}$ \\
\hline $\mathbf{A}$ & 0.831 & 0.988 & 1.034 & 1.025 & 1.177 & 1.189 & 0.884 & 0.854 & 0.875 & 0.887 & 0.945 & 0.963 \\
\hline $\mathbf{B}$ & 1.086 & 0.804 & 1.004 & 1.053 & 0.957 & 1.105 & 0.779 & 0.745 & 0.845 & 0.888 & 0.912 & 0.942 \\
\hline $\mathbf{C}$ & 1.22 & 0.791 & 0.753 & 1.058 & 0.951 & 1.062 & 0.703 & 0.81 & 0.881 & 0.813 & 0.92 & 0.944 \\
\hline $\mathbf{D}$ & 0.654 & 0.724 & 0.763 & 1.057 & 0.977 & 1.174 & 0.862 & 0.84 & 0.852 & 0.923 & 0.946 & 0.96 \\
\hline $\mathbf{E}$ & 0.654 & 0.685 & 1.019 & 1.138 & 1.078 & 1.196 & 0.684 & 0.715 & 0.84 & 0.849 & 0.844 & 0.847 \\
\hline $\mathbf{F}$ & 0.746 & 0.82 & 1.039 & 1.123 & 1.182 & 1.173 & 0.689 & 0.759 & 0.826 & 0.842 & 0.844 & 0.853 \\
\hline $\mathbf{G}$ & 0.803 & 0.83 & 1.099 & 0.85 & 1.194 & 1.231 & 0.684 & 0.784 & 0.808 & 0.83 & 0.849 & 0.843 \\
\hline $\mathbf{H}$ & 0.906 & 0.982 & 1.047 & 1.064 & 1.194 & 1.116 & 0.964 & 0.763 & 0.769 & 0.83 & 0.772 & $\mathbf{0 . 8 4 0}$ \\
\hline
\end{tabular}

The selected OD value is shown in bold font.

Table.10 Chequer board titration for LPS antigen: 1:5 antigen dilution

\begin{tabular}{|c|c|c|c|c|c|c|c|c|c|c|c|c|}
\hline & $\mathbf{1}$ & $\mathbf{2}$ & $\mathbf{3}$ & $\mathbf{4}$ & $\mathbf{5}$ & $\mathbf{6}$ & $\mathbf{7}$ & $\mathbf{8}$ & $\mathbf{9}$ & $\mathbf{1 0}$ & $\mathbf{1 1}$ & $\mathbf{1 2}$ \\
\hline $\mathbf{A}$ & 0.847 & 0.409 & 0.337 & 0.236 & 0.172 & 0.104 & 0.609 & 0.352 & 0.295 & 0.189 & 0.183 & 0.130 \\
\hline $\mathbf{B}$ & 1.120 & 0.624 & 0.429 & 0.338 & 0.380 & 0.237 & 0.984 & 0.653 & 0.481 & 0.291 & 0.269 & 0.220 \\
\hline $\mathbf{C}$ & 1.229 & 0.810 & 0.579 & 0.433 & 0.390 & 0.246 & 1.051 & 0.680 & 0.488 & 0.347 & 0.306 & 0.239 \\
\hline $\mathbf{D}$ & 1.247 & 0.648 & 0.379 & 0.378 & 0.313 & 0.238 & 0.963 & 0.614 & 0.411 & 0.316 & 0.272 & 0.212 \\
\hline $\mathbf{E}$ & 0.530 & 0.252 & 0.153 & 0.121 & 0.112 & 0.085 & 0.433 & 0.250 & 0.111 & 0.115 & 0.105 & 0.112 \\
\hline $\mathbf{F}$ & 0.830 & 0.426 & 0.274 & 0.203 & 0.201 & 0.135 & 0.787 & 0.475 & 0.303 & 0.198 & 0.181 & 0.135 \\
\hline $\mathbf{G}$ & 1.034 & 0.511 & 0.294 & 0.251 & 0.186 & 0.140 & 0.702 & 0.421 & 0.340 & 0.217 & 0.192 & 0.150 \\
\hline $\mathbf{H}$ & 1.084 & 0.456 & 0.394 & 0.272 & 0.217 & 0.177 & 0.843 & 0.427 & 0.387 & 0.266 & $\mathbf{0 . 2 0 6}$ & 0.156 \\
\hline
\end{tabular}

The selected OD value is shown in bold font

Table.11 Chequer board titration for LPS antigen: 1:50 antigen dilution

\begin{tabular}{|c|c|c|c|c|c|c|c|c|c|c|c|c|}
\hline & $\mathbf{1}$ & $\mathbf{2}$ & $\mathbf{3}$ & $\mathbf{4}$ & $\mathbf{5}$ & $\mathbf{6}$ & $\mathbf{7}$ & $\mathbf{8}$ & $\mathbf{9}$ & $\mathbf{1 0}$ & $\mathbf{1 1}$ & $\mathbf{1 2}$ \\
\hline $\mathbf{A}$ & 0.410 & 0.217 & 0.159 & 0.114 & 0.099 & 0.074 & 0.440 & 0.200 & 0.144 & 0.090 & 0.143 & 0.087 \\
\hline $\mathbf{B}$ & 0.514 & 0.337 & 0.227 & 0.149 & 0.099 & 0.099 & 0.535 & 0.303 & 0.222 & 0.140 & 0.064 & 0.086 \\
\hline C & 0.529 & 0.304 & 0.216 & 0.133 & 0.087 & 0.086 & 0.533 & 0.261 & 0.191 & 0.121 & 0.051 & 0.085 \\
\hline D & 0.499 & 0.276 & 0.212 & 0.146 & 0.071 & 0.081 & 0.382 & 0.222 & 0.192 & 0.108 & 0.066 & 0.073 \\
\hline $\mathbf{E}$ & 0.391 & 0.134 & 0.085 & 0.064 & 0.067 & 0.052 & 0.268 & 0.141 & 0.105 & 0.084 & 0.071 & 0.070 \\
\hline F & 0.496 & 0.187 & 0.145 & 0.132 & 0.070 & 0.058 & 0.326 & 0.199 & 0.132 & 0.093 & 0.078 & 0.063 \\
\hline $\mathbf{G}$ & 0.470 & 0.176 & 0.146 & 0.103 & 0.069 & 0.064 & 0.293 & 0.197 & 0.165 & 0.102 & 0.060 & 0.080 \\
\hline H & 0.626 & 0.169 & 0.162 & 0.095 & 0.058 & 0.060 & 0.379 & 0.188 & 0.143 & 0.101 & 0.059 & 0.061 \\
\hline
\end{tabular}

Table.12 Chequer board titration for LPS antigen: 1:100 antigen dilution

\begin{tabular}{|c|c|c|c|c|c|c|c|c|c|c|c|c|}
\hline & $\mathbf{1}$ & $\mathbf{2}$ & $\mathbf{3}$ & $\mathbf{4}$ & $\mathbf{5}$ & $\mathbf{6}$ & $\mathbf{7}$ & $\mathbf{8}$ & $\mathbf{9}$ & $\mathbf{1 0}$ & $\mathbf{1 1}$ & $\mathbf{1 2}$ \\
\hline $\mathbf{A}$ & 0.425 & 0.164 & 0.112 & 0.069 & 0.077 & 0.050 & 0.352 & 0.157 & 0.112 & 0.069 & 0.056 & 0.047 \\
\hline $\mathbf{B}$ & 0.405 & 0.174 & 0.619 & 0.089 & 0.077 & 0.065 & 0.483 & 0.225 & 0.146 & 0.096 & 0.064 & 0.055 \\
\hline $\mathbf{C}$ & 0.463 & 0.162 & 0.089 & 0.111 & 0.067 & 0.059 & 0.349 & 0.127 & 0.088 & 0.064 & 0.055 & 0.052 \\
\hline $\mathbf{D}$ & 0.482 & 0.151 & 0.099 & 0.093 & 0.054 & 0.054 & 0.304 & 0.161 & 0.108 & 0.091 & 0.087 & 0.052 \\
\hline $\mathbf{E}$ & 0.380 & 0.148 & 0.092 & 0.069 & 0.074 & 0.054 & 0.232 & 0.109 & 0.084 & 0.067 & 0.061 & 0.084 \\
\hline F & 0.385 & 0.144 & 0.102 & 0.067 & 0.050 & 0.057 & 0.255 & 0.137 & 0.076 & 0.060 & 0.051 & 0.044 \\
\hline $\mathbf{G}$ & 0.365 & 0.141 & 0.211 & 0.118 & 0.053 & 0.043 & 0.236 & 0.112 & 0.074 & 0.057 & 0.048 & 0.056 \\
\hline $\mathbf{H}$ & 0.357 & 0.174 & 0.090 & 0.069 & 0.059 & 0.045 & 0.212 & 0.116 & 0.164 & 0.054 & 0.058 & 0.43 \\
\hline
\end{tabular}


Table.13 Mean, standard deviation and coefficient of variation for whole killed bacterial cell antigen

\begin{tabular}{|c|c|c|c|c|c|c|c|c|c|c|}
\hline & & & Iean & & & d. Dev & & & $\mathrm{CV}$ & \\
\hline & & Anti & n Diluti & & Anti & n Dilt & & & igen Dilu & \\
\hline & & Undil Ag & $1: 5$ & 1:10 & $\begin{array}{c}\text { Undil } \\
\text { Ag }\end{array}$ & $1: 5$ & 1:10 & $\begin{array}{c}\text { Undil } \\
\text { Ag }\end{array}$ & $1: 5$ & 1:10 \\
\hline Day-1 & Plate-1 & 0.799 & 0.198 & 0.161 & 0.08 & 0.03 & 0.03 & $10.24 \%$ & $17.27 \%$ & $18.01 \%$ \\
\hline & Plate-2 & 0.663 & 0.174 & 0.155 & 0.09 & 0.04 & 0.03 & $13.95 \%$ & $21.74 \%$ & $19.35 \%$ \\
\hline & Plate-3 & 0.623 & 0.172 & 0.129 & 0.09 & 0.04 & 0.02 & $14.43 \%$ & $21.61 \%$ & $18.60 \%$ \\
\hline & Inter plate & 0.593 & 0.182 & 0.150 & 0.12 & 0.04 & 0.03 & $19.45 \%$ & $20.87 \%$ & $20.67 \%$ \\
\hline Day-2 & Plate-1 & 0.703 & 0.170 & 0.111 & 0.08 & 0.03 & 0.02 & $11.26 \%$ & $20.23 \%$ & $17.70 \%$ \\
\hline & Plate-2 & 0.676 & 0.194 & 0.135 & 0.10 & 0.04 & 0.03 & $14.87 \%$ & $19.62 \%$ & $20.91 \%$ \\
\hline & Plate-3 & 0.644 & 0.148 & 0.152 & 0.07 & 0.03 & 0.03 & $11.14 \%$ & $23.42 \%$ & $17.23 \%$ \\
\hline & Inter plate & 0.674 & 0.170 & 0.137 & 0.09 & 0.04 & 0.02 & $12.90 \%$ & $23.78 \%$ & $14.60 \%$ \\
\hline & Plate-1 & 0.619 & 0.216 & 0.162 & 0.10 & 0.04 & 0.03 & $16.31 \%$ & $19.20 \%$ & $17.87 \%$ \\
\hline Day-3 & Plate-2 & 0.637 & 0.178 & 0.128 & 0.09 & 0.04 & 0.03 & $14.56 \%$ & $23.38 \%$ & $25.50 \%$ \\
\hline & Plate-3 & 0.632 & 0.168 & 0.140 & 0.10 & 0.04 & 0.02 & $15.28 \%$ & $23.33 \%$ & $15.73 \%$ \\
\hline & Inter plate & 0.629 & 0.187 & 0.143 & 0.10 & 0.04 & 0.03 & $15.21 \%$ & $23.50 \%$ & $19.37 \%$ \\
\hline Inter-days & & 0.666 & 0.180 & 0.146 & 0.10 & 0.03 & 0.03 & $15.51 \%$ & $16.68 \%$ & $20.55 \%$ \\
\hline
\end{tabular}

Table.14 Mean, standard deviation and coefficient of variation for sonicated antigen

\begin{tabular}{|c|c|c|c|c|c|c|c|c|c|c|}
\hline & & \multicolumn{3}{|c|}{ Mean } & \multicolumn{3}{|c|}{ Std.Dev } & \multicolumn{3}{|c|}{ CV } \\
\hline & & \multicolumn{3}{|c|}{ Antigen Dilution } & \multicolumn{3}{|c|}{ Antigen Dilution } & \multicolumn{3}{|c|}{ Antigen Dilution } \\
\hline & & $1: 5$ & 1:10 & $1: 50$ & $1: 5$ & 1:10 & $1: 50$ & $1: 5$ & $1: 10$ & $1: 50$ \\
\hline \multirow[t]{4}{*}{ Day-1 } & Plate-1 & 0.754 & 0.505 & 0.142 & 0.07 & 0.05 & 0.02 & $9.03 \%$ & $10.07 \%$ & $15.46 \%$ \\
\hline & Plate-2 & 0.725 & 0.452 & 0.132 & 0.06 & 0.06 & 0.03 & $8.28 \%$ & $12.72 \%$ & $20.45 \%$ \\
\hline & Plate-3 & 0.781 & 0.530 & 0.159 & 0.06 & 0.03 & 0.02 & $8.30 \%$ & $5.66 \%$ & $12.60 \%$ \\
\hline & Inter plate & 0.754 & 0.503 & 0.145 & 0.07 & 0.06 & 0.03 & $9.12 \%$ & $11.36 \%$ & $18.63 \%$ \\
\hline \multirow[t]{5}{*}{ Day-2 } & Plate-1 & 0.933 & 0.686 & 0.217 & 0.13 & 0.11 & 0.04 & $13.45 \%$ & $15.91 \%$ & $19.13 \%$ \\
\hline & Plate-2 & 0.825 & 0.622 & 0.148 & 0.08 & 0.08 & 0.03 & $9.44 \%$ & $13.06 \%$ & $20.64 \%$ \\
\hline & Plate-3 & 0.861 & 0.658 & 0.187 & 0.09 & 0.07 & 0.04 & $10.49 \%$ & $10.52 \%$ & $20.19 \%$ \\
\hline & Inter plate & 0.873 & 0.655 & 0.180 & 0.11 & 0.09 & 0.03 & $12.43 \%$ & $13.85 \%$ & $16.67 \%$ \\
\hline & Plate-1 & 0.919 & 0.698 & 0.203 & 0.08 & 0.07 & 0.02 & $9.15 \%$ & $10.03 \%$ & $11.33 \%$ \\
\hline \multirow[t]{3}{*}{ Day-3 } & Plate-2 & 0.842 & 0.629 & 0.188 & 0.12 & 0.06 & 0.03 & $14.25 \%$ & $8.88 \%$ & $13.66 \%$ \\
\hline & Plate-3 & 0.833 & 0.612 & 0.202 & 0.07 & 0.04 & 0.03 & $7.85 \%$ & $6.40 \%$ & $16.38 \%$ \\
\hline & Inter plate & 0.864 & 0.646 & 0.197 & 0.10 & 0.07 & 0.03 & $11.53 \%$ & $10.39 \%$ & $14.18 \%$ \\
\hline Inter-days & & 0.830 & 0.602 & 0.174 & 0.11 & 0.10 & 0.03 & $13.02 \%$ & $16.75 \%$ & $17.24 \%$ \\
\hline
\end{tabular}


Table.15 Mean, standard deviation and coefficient of variation for LPS antigen

\begin{tabular}{|c|c|c|c|c|c|c|c|c|c|c|}
\hline & & \multicolumn{3}{|c|}{ Mean } & \multicolumn{3}{c|}{ Std.Dev } & \multicolumn{3}{c|}{ CV } \\
\hline & & \multicolumn{3}{|c}{ Antigen Dilution } & \multicolumn{2}{c|}{ Antigen Dilution } & \multicolumn{3}{c|}{ Antigen Dilution } \\
\hline \multirow{3}{*}{ Day-1 } & & $\mathbf{1 : 5}$ & $\mathbf{1 : 1 0}$ & $\mathbf{1 : 5 0}$ & $\mathbf{1 : 5}$ & $\mathbf{1 : 1 0}$ & $\mathbf{1 : 5 0}$ & $\mathbf{1 : 5}$ & $\mathbf{1 : 1 0}$ & $\mathbf{1 : 5 0}$ \\
& Plate-1 & 0.450 & 0.365 & 0.207 & 0.07 & 0.04 & 0.04 & $15.68 \%$ & $11.31 \%$ & $18.55 \%$ \\
\cline { 2 - 12 } & Plate-2 & 0.468 & 0.372 & 0.185 & 0.06 & 0.05 & 0.04 & $12.61 \%$ & $12.11 \%$ & $18.92 \%$ \\
\cline { 2 - 11 } & Plate-3 & 0.479 & 0.405 & 0.214 & 0.05 & 0.03 & 0.03 & $9.44 \%$ & $7.28 \%$ & $14.49 \%$ \\
\cline { 2 - 11 } & Inter plate & 0.466 & 0.382 & 0.203 & 0.06 & 0.04 & 0.04 & $12.79 \%$ & $11.07 \%$ & $17.78 \%$ \\
\hline \hline \multirow{2}{*}{ Day-2 } & Plate-1 & 0.697 & 0.614 & 0.318 & 0.07 & 0.07 & 0.06 & $10.34 \%$ & $11.54 \%$ & $18.04 \%$ \\
\cline { 2 - 11 } & Plate-2 & 0.602 & 0.504 & 0.284 & 0.07 & 0.04 & 0.03 & $11.01 \%$ & $7.69 \%$ & $11.97 \%$ \\
\cline { 2 - 10 } & Plate-3 & 0.560 & 0.484 & 0.261 & 0.06 & 0.04 & 0.03 & $10.64 \%$ & $8.73 \%$ & $11.13 \%$ \\
\hline \multirow{3}{*}{ Day-3 } & Inter plate & 0.620 & 0.534 & 0.284 & 0.09 & 0.08 & 0.04 & $14.07 \%$ & $14.50 \%$ & $15.49 \%$ \\
\hline & Plate-1 & 0.613 & 0.522 & 0.297 & 0.06 & 0.08 & 0.04 & $10.52 \%$ & $15.03 \%$ & $13.47 \%$ \\
\hline & Plate-2 & 0.523 & 0.420 & 0.218 & 0.06 & 0.07 & 0.04 & $11.94 \%$ & $15.98 \%$ & $16.69 \%$ \\
\hline \hline Inter-days & Plate-3 & 0.502 & 0.394 & 0.213 & 0.07 & 0.04 & 0.03 & $14.00 \%$ & $10.38 \%$ & $14.55 \%$ \\
\hline & Inter plate & 0.546 & 0.445 & 0.236 & 0.08 & 0.08 & 0.05 & $14.86 \%$ & $17.20 \%$ & $19.49 \%$ \\
\hline
\end{tabular}

Table.16 Cut off values for whole killed bacterial cell, sonicated and LPS antigens

\begin{tabular}{|c|c|c|c|c|c|c|c|c|}
\hline \multicolumn{2}{|c|}{} & Mean & SD & Mean + 3SD & $\begin{array}{c}\text { Value } \\
\text { exceeding } \\
\text { Mean + 3SD }\end{array}$ & $\begin{array}{c}\text { \% of } \\
\text { Value } \\
\text { Exceeding }\end{array}$ & $\begin{array}{c}\text { Maximum } \\
\text { Exceeding }\end{array}$ \\
\hline $\begin{array}{c}\text { Sonicated } \\
\text { Antigen }\end{array}$ & $\begin{array}{c}\text { With antigen } \\
\text { (neg ascites) }\end{array}$ & 0.03 & 0.005 & 0.06 & 0 & & & \\
\hline & Without antigen & 0.05 & 0.008 & 0.074 & 1 & $1 \%$ & 0.086 \\
\hline $\begin{array}{c}\text { LPS } \\
\text { Antigen }\end{array}$ & $\begin{array}{c}\text { With antigen } \\
\text { (neg ascites) }\end{array}$ & 0.05 & 0.011 & 0.084 & 0 & & & \\
\cline { 2 - 9 } & Without antigen & 0.06 & 0.01 & 0.1 & 0 & & & \\
\hline $\begin{array}{c}\text { Whole Killed } \\
\text { Bacterial } \\
\text { Antigen }\end{array}$ & $\begin{array}{c}\text { With antigen } \\
\text { (neg ascites) }\end{array}$ & 0.05 & 0.009 & 0.08 & 0 & & & \\
\hline & Without antigen & 0.058 & 0.018 & 0.112 & 0 & & & \\
\hline
\end{tabular}

Table.17 OD values for estimation of the ELISA titre of whole killed bacterial cell antigen

\begin{tabular}{|c|c|c|}
\hline & $\mathbf{1}$ & $\mathbf{2}$ \\
\hline A & Blank & Blank \\
\hline B & $0.292(1: 5)$ & $0.283(1: 5)$ \\
\hline C & $0.242(1: 10)$ & $0.221(1: 10)$ \\
\hline D & $0.186(1: 20)$ & $0.182(1: 20)$ \\
\hline E & $0.151(1: 40)$ & $0.156(1: 40)$ \\
\hline F & $0.112(1: 80)$ & $0.136(1: 80)$ \\
\hline G & $0.119(1: 160)$ & $0.128(1: 160)$ \\
\hline H & $0.114(1: 320)$ & $0.11(1: 320)$ \\
\hline
\end{tabular}


Table.18 OD values for estimation of the ELISA titre of sonicated antigen

\begin{tabular}{|c|c|c|c|c|c|c|c|c|c|c|c|c|}
\hline & $\mathbf{1}$ & $\mathbf{2}$ & $\mathbf{3}$ & $\mathbf{4}$ & $\mathbf{5}$ & $\mathbf{6}$ & $\mathbf{7}$ & $\mathbf{8}$ & $\mathbf{9}$ & $\mathbf{1 0}$ & $\mathbf{1 1}$ & $\mathbf{1 2}$ \\
\hline $\mathbf{A}$ & Blank & Blank & Blank & Blank & Blank & Blank & Blank & Blank & Blank & Blank & Blank & Blank \\
\hline B & 0.55 & 0.417 & 0.249 & 0.159 & 0.089 & 0.062 & 0.055 & 0.049 & 0.041 & 0.044 & 0.043 & 0.051 \\
\hline C & 0.625 & 0.387 & 0.184 & 0.152 & 0.08 & 0.053 & 0.058 & 0.05 & 0.045 & 0.052 & 0.055 & 0.055 \\
\hline D & 0.625 & 0.38 & 0.208 & 0.124 & 0.08 & 0.055 & 0.048 & 0.048 & 0.045 & 0.047 & 0.048 & 0.061 \\
\hline
\end{tabular}

Table.19 OD values for estimation of the ELISA titre of LPS antigen

\begin{tabular}{|c|c|c|c|c|c|c|c|c|c|c|c|c|}
\hline & $\mathbf{1}$ & $\mathbf{2}$ & $\mathbf{3}$ & $\mathbf{4}$ & $\mathbf{5}$ & $\mathbf{6}$ & $\mathbf{7}$ & $\mathbf{8}$ & $\mathbf{9}$ & $\mathbf{1 0}$ & $\mathbf{1 1}$ & $\mathbf{1 2}$ \\
\hline $\mathbf{A}$ & Blank & Blank & Blank & Blank & Blank & Blank & Blank & Blank & Blank & Blank & Blank & Blank \\
\hline B & 0.764 & 0.532 & 0.404 & 0.293 & 0.18 & 0.12 & 0.111 & 0.069 & 0.074 & 0.059 & 0.052 & 0.071 \\
\hline C & 0.737 & 0.588 & 0.446 & 0.265 & 0.203 & 0.136 & 0.09 & 0.071 & 0.133 & 0.074 & 0.065 & 0.072 \\
\hline D & 0.804 & 0.592 & 0.478 & 0.303 & 0.218 & 0.127 & 0.108 & 0.08 & 0.077 & 0.068 & 0.06 & 0.07 \\
\hline
\end{tabular}

Table.20 Analytical specificity of $P$. multocida type B against $P$. multocida Type A bovine strain (whole killed bacterial cell antigen, sonicated and LPS antigens): ELISA OD values

\begin{tabular}{|c|c|c|c|c|}
\hline & $\mathbf{1}$ & $\mathbf{2}$ & $\mathbf{3}$ & $\mathbf{4}$ \\
\hline $\mathbf{A}$ & 0.132 & 0.13 & 0.07 & 0.07 \\
\hline $\mathbf{B}$ & -0.025 & -0.038 & -0.001 & 0.003 \\
\hline $\mathbf{C}$ & -0.041 & -0.037 & 0.002 & 0.016 \\
\hline $\mathbf{D}$ & 0.823 & 0.891 & 1.012 & 0.907 \\
\hline $\mathbf{E}$ & 0.14 & 0.14 & & \\
\hline $\mathbf{F}$ & 0.060 & -0.002 & & \\
\hline $\mathbf{G}$ & 0.013 & 0.038 & & \\
\hline $\mathbf{H}$ & 1.259 & 0.973 & & \\
\hline
\end{tabular}

Table.21 Isolation of bacteria, The ELISA test and PCR on heart blood samples

\begin{tabular}{|c|l|c|c|c|}
\hline Post-infection & Signs and Symptoms & Bacteria Isolated & PCR & ELISA \\
\hline $\mathbf{2} \mathbf{~ h}$ & No apparent symptoms & $-\mathrm{ve}$ & -ve & +ve \\
\hline $\mathbf{4} \mathbf{~ h}$ & No apparent symptoms & $-\mathrm{ve}$ & +ve & +ve \\
\hline $\mathbf{8} \mathbf{~ h}$ & No apparent symptoms (huddling) & +ve & +ve & +ve \\
\hline $\mathbf{1 2} \mathbf{~ h}$ & No apparent symptoms(huddling) & +ve & +ve & +ve \\
\hline $\mathbf{2 4} \mathbf{~ h}$ & Mouse found dead & +ve & +ve & +ve \\
\hline
\end{tabular}


Fig.1

\begin{tabular}{|c|c|c|c|c|c|c|c|c|c|c|c|c|c|}
\hline & Di & ution & $\begin{array}{l}\text { of a } \\
\text { Col }\end{array}$ & $\begin{array}{l}\rightarrow \\
\text { mo } \\
\text { gat }\end{array}$ & $-H$ & & & & ti & $\begin{array}{r}\text { of a } \\
\text { Co }\end{array}$ & $\begin{array}{l}\text { i mo } \\
\text { ugat }\end{array}$ & e-HI & \\
\hline \multirow{3}{*}{\begin{tabular}{|c} 
Dilution \\
Of \\
$\downarrow$ coating
\end{tabular}} & & 1 & 2 & 3 & 4 & 5 & 6 & 7 & 8 & 9 & 10 & 11 & 12 \\
\hline & $\mathbf{A}$ & & & & & & & & & & & & \\
\hline & B & \multicolumn{4}{|c|}{ Monoclonal antibody } & & & & & \multicolumn{4}{|c|}{ Monoclonal antibody } \\
\hline \multirow[t]{2}{*}{ Serum } & $\mathbf{C}$ & & \multicolumn{3}{|c|}{$\begin{array}{l}\text { Dilution } \\
\text { A(1:500) }\end{array}$} & & & & & & \multicolumn{3}{|c|}{$\begin{array}{l}\text { dilution- } \\
\mathrm{B}(\mathbf{1 : 8 0 0 )}\end{array}$} \\
\hline & D & & & & & & & & & & & & \\
\hline Dilution & $\mathbf{E}$ & & & & & & & & & & & & \\
\hline$\downarrow \quad$ Of & $\mathbf{F}$ & & \multicolumn{4}{|c|}{ Monoclonal antibody } & & & & \multicolumn{4}{|c|}{ Monoclonal antibody } \\
\hline coating & $\mathbf{G}$ & & & \multicolumn{3}{|c|}{$\begin{array}{l}\text { dilution- } \\
\mathrm{C}(1: 1000)\end{array}$} & & & & & \multicolumn{3}{|c|}{$\begin{array}{l}\text { dilution- } \\
\mathrm{D}(1: 1500)\end{array}$} \\
\hline Serum & $\mathbf{H}$ & & & & & & & & & & & & \\
\hline
\end{tabular}

Fig.2

\begin{tabular}{|c|c|c|c|c|}
\hline & 1 & 2 & $\mathbf{3}$ & $\mathbf{4}$ \\
\hline $\mathbf{A}$ & Blank & Blank & $\begin{array}{l}\text { Undiluted blood sample } \\
\text { of } 12 \mathrm{~h} \text { sampling }\end{array}$ & $\begin{array}{l}\text { Undiluted blood sample of } \\
12 \mathrm{~h} \text { sampling }\end{array}$ \\
\hline B & $\begin{array}{l}\text { Undiluted blood sample } \\
\text { of } 2 \mathrm{~h} \text { sampling }\end{array}$ & $\begin{array}{l}\text { Undiluted blood sample } \\
\text { of } 2 \mathrm{~h} \text { sampling }\end{array}$ & $\begin{array}{l}1: 2 \text { diluted blood sample } \\
\text { of } 12 \mathrm{~h} \text { sampling }\end{array}$ & $\begin{array}{l}\text { 1:2 diluted blood sample } \\
\text { of } 12 \mathrm{~h} \text { sampling }\end{array}$ \\
\hline $\mathbf{C}$ & $\begin{array}{l}1: 2 \text { diluted blood sample } \\
\text { of } 2 \mathrm{~h} \text { sampling }\end{array}$ & $\begin{array}{l}\text { 1:2 diluted blood sample } \\
\text { of } 2 \mathrm{~h} \text { sampling }\end{array}$ & $\begin{array}{l}\text { Undiluted blood sample } \\
\text { of } 24 \mathrm{~h} \text { sampling }\end{array}$ & $\begin{array}{l}\text { Undiluted blood sample of } \\
24 \mathrm{~h} \text { sampling }\end{array}$ \\
\hline D & $\begin{array}{l}\text { Undiluted blood sample } \\
\text { of } 4 \mathrm{~h} \text { sampling }\end{array}$ & $\begin{array}{l}\text { Undiluted blood sample } \\
\text { of } 4 \mathrm{~h} \text { sampling }\end{array}$ & $\begin{array}{l}\text { 1:2 diluted blood sample } \\
\text { of } 24 \mathrm{~h} \text { sampling }\end{array}$ & $\begin{array}{l}\text { 1:2 diluted blood sample } \\
\text { of } 24 \mathrm{~h} \text { sampling }\end{array}$ \\
\hline $\mathbf{E}$ & $\begin{array}{l}\text { 1:2 diluted blood sample } \\
\text { of } 4 \mathrm{~h} \text { sampling }\end{array}$ & $\begin{array}{l}\text { 1:2 diluted blood sample } \\
\text { of } 4 \mathrm{~h} \text { sampling }\end{array}$ & $\begin{array}{l}\text { Undiluted blood of } \\
\text { negative control }\end{array}$ & $\begin{array}{l}\text { Undiluted blood sample of } \\
\text { negative control }\end{array}$ \\
\hline $\mathbf{F}$ & $\begin{array}{l}\text { Undiluted blood sample } \\
\text { of } 8 \mathrm{~h} \text { sampling }\end{array}$ & $\begin{array}{l}\text { Undiluted blood sample } \\
\text { of } 8 \mathrm{~h} \text { sampling }\end{array}$ & $\begin{array}{l}1: 2 \text { diluted blood sample } \\
\text { of negative control }\end{array}$ & $\begin{array}{l}1: 2 \text { diluted blood sample } \\
\text { of negative control }\end{array}$ \\
\hline G & $\begin{array}{c}\text { 1:2 diluted blood sample } \\
\text { of } 8 \mathrm{~h} \text { sampling }\end{array}$ & $\begin{array}{l}\text { 1:2 diluted blood sample } \\
\text { of } 8 \mathrm{~h} \text { sampling }\end{array}$ & & \\
\hline $\mathbf{H}$ & Positive Control & Positive Control & Positive Control & Positive Control \\
\hline
\end{tabular}

Fig.3

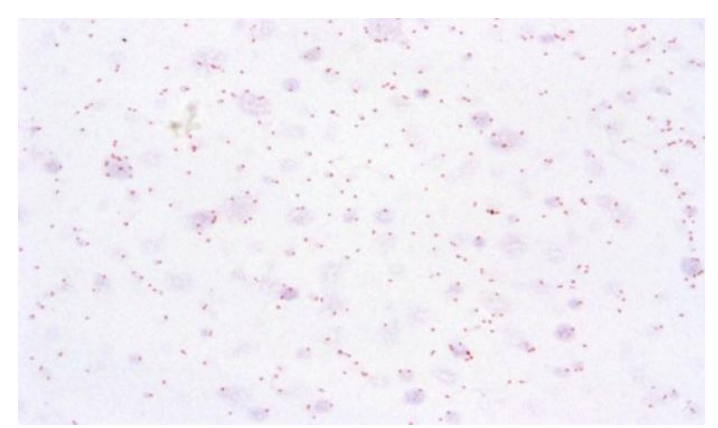

A

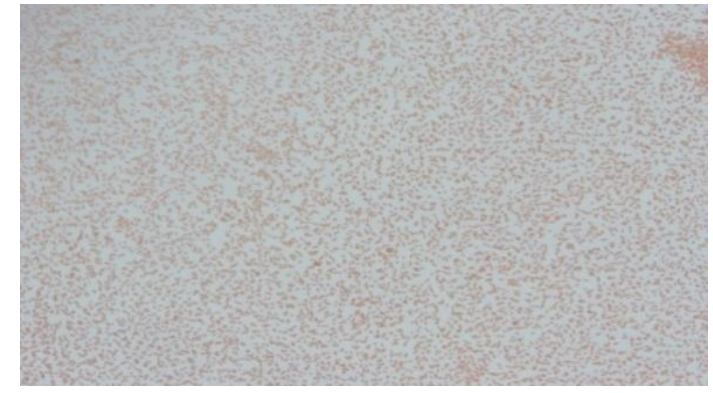

B 
Fig.4

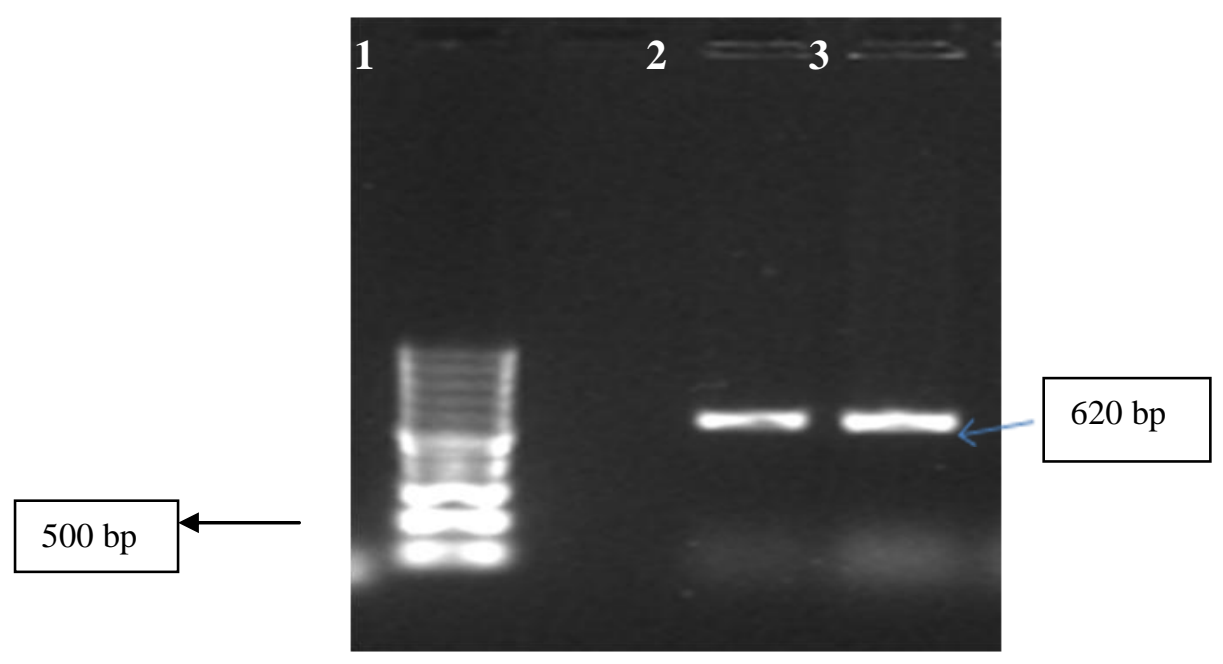

Fig.5

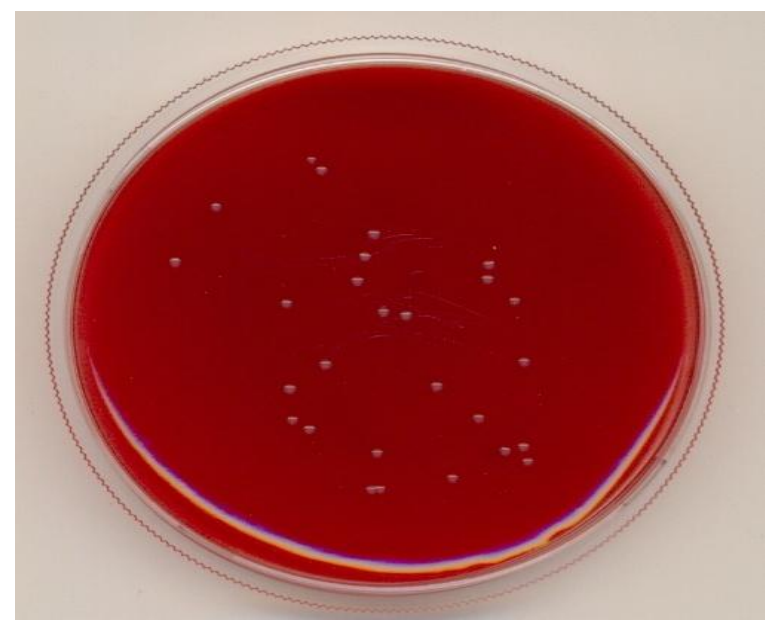

Fig.6

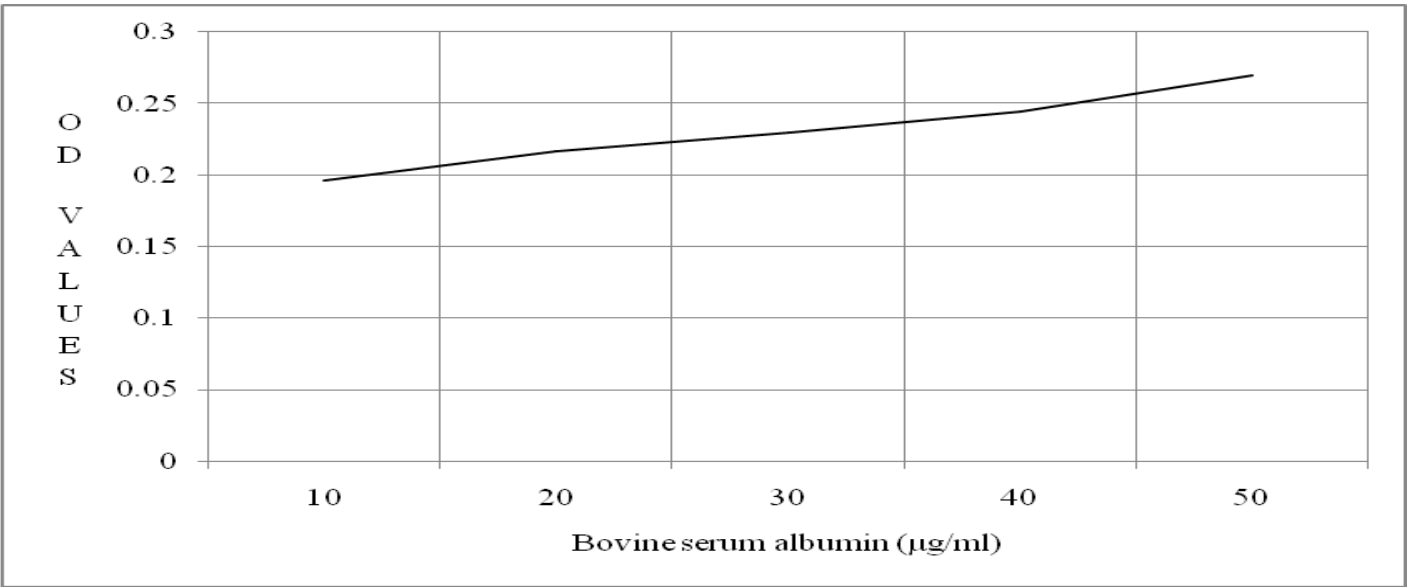


Fig.7

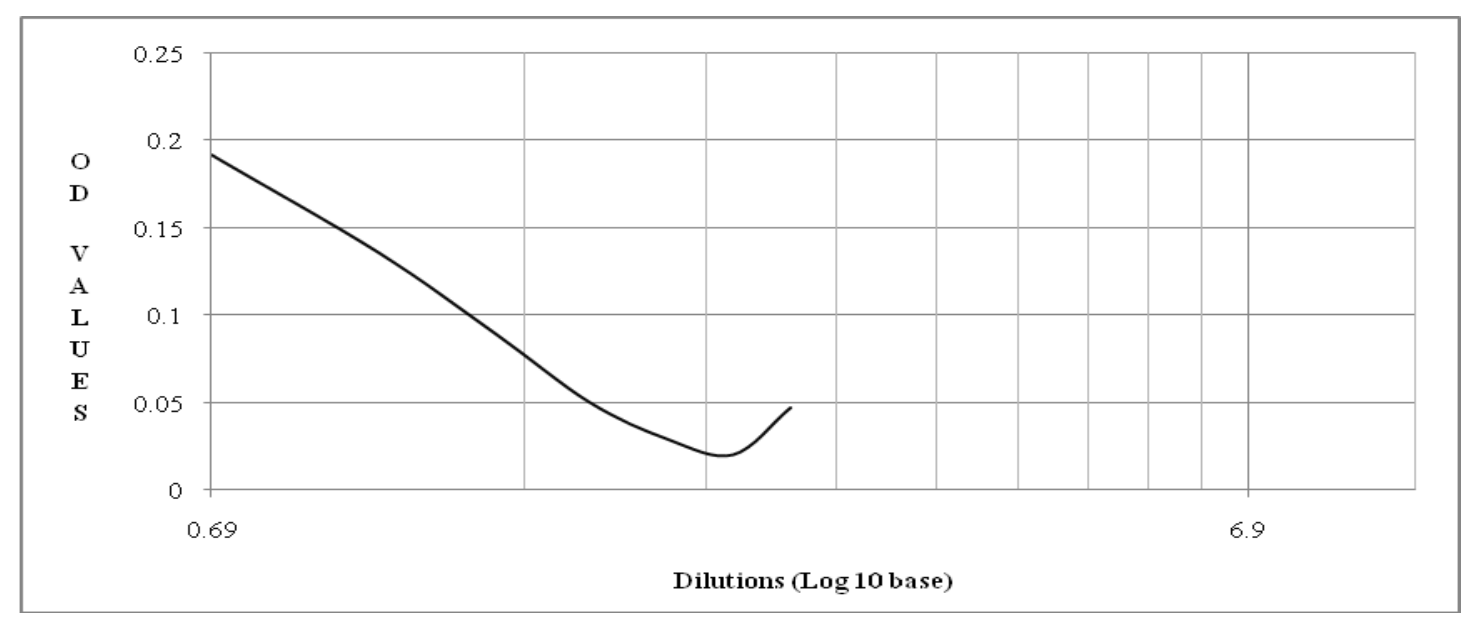

Fig.8

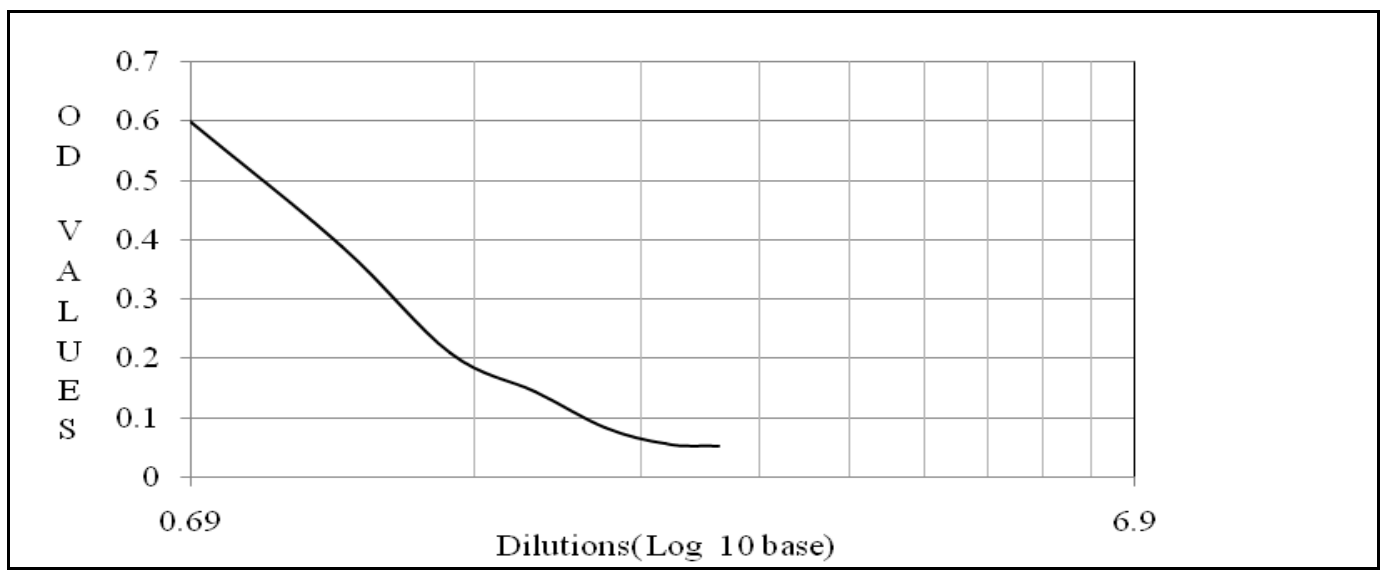

Fig.9

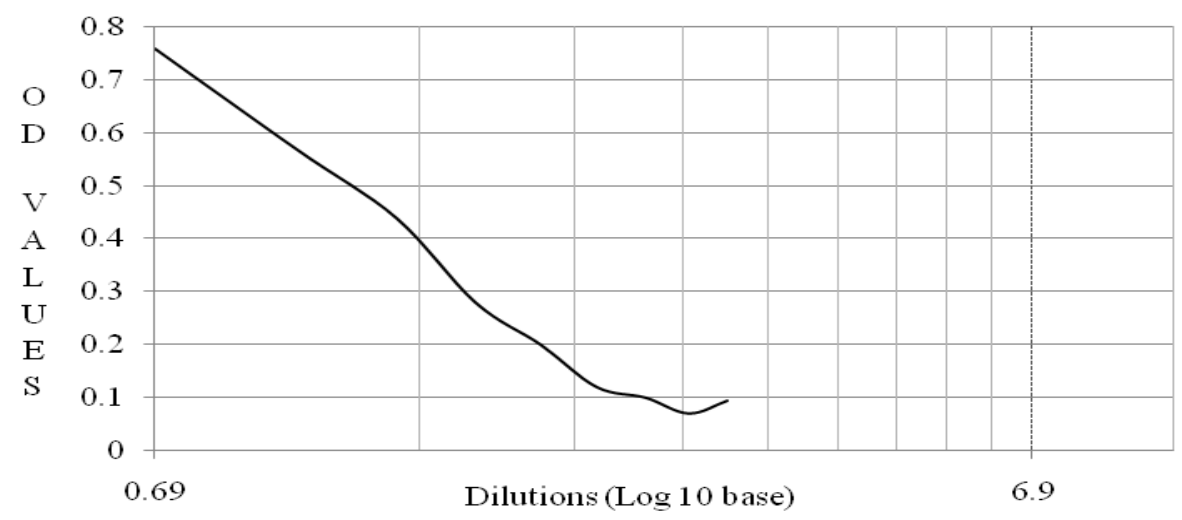


Fig.10

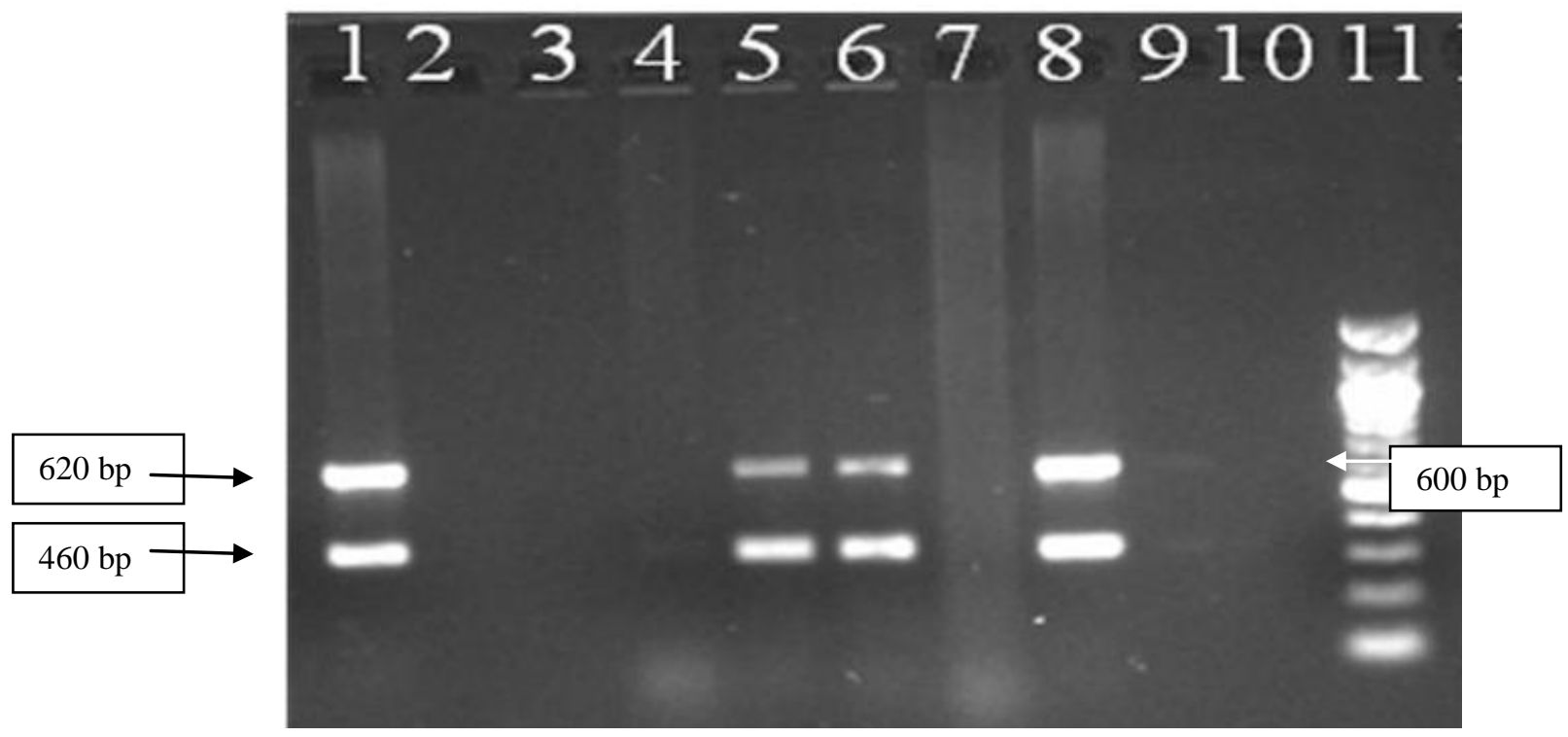

Fig.11

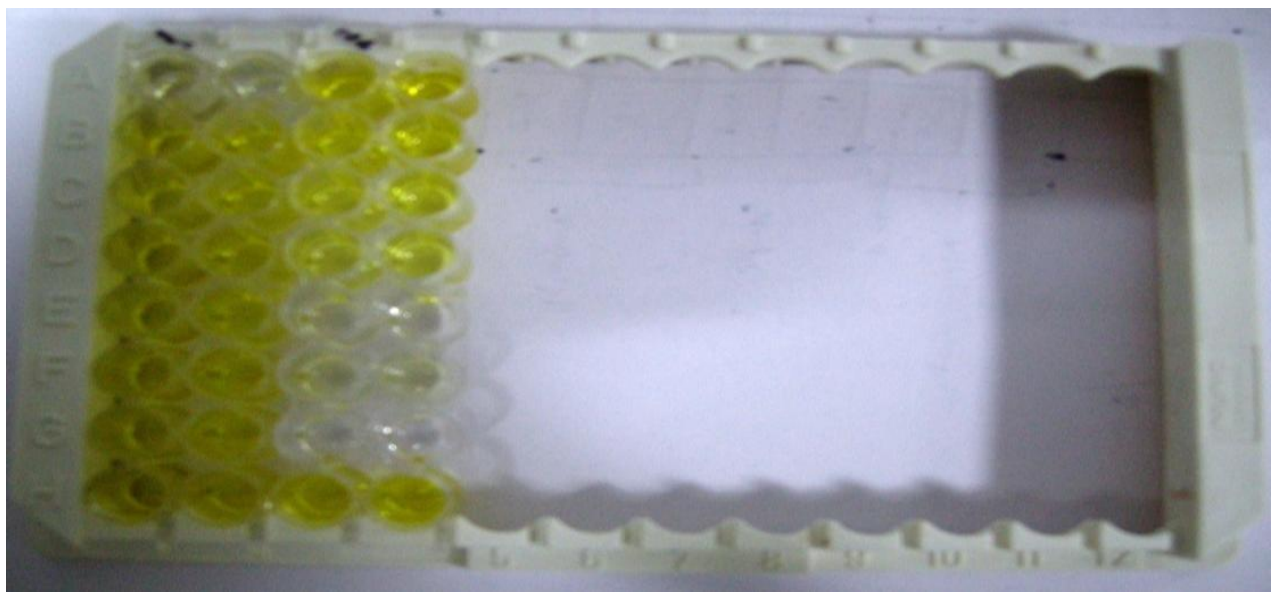

Therefore, it cannot remove errors committed during replication, and stalls at the mismatches, and may even give up replication. Shorter length of amplicon tends to increase amplification efficiency. Small sized amplicons are more tolerant of reaction conditions because they are more likely to be denatured during the $92-95^{\circ} \mathrm{C}$ step of the $\mathrm{PCR}$, allowing the primers to bind more efficiently.

The $P$. multocida appeared in the blood as early as $4 \mathrm{~h}$ post infection. However, the amount of bacteria was low. Therefore, it could not be isolated from heart blood of mice sacrificed at $4 \mathrm{~h}$ post infection. Material collected from clinically affected animals before death may not give consistent results. Blood will give positive cultures only in the terminal stage immediately before death (De Alwis, 1999). In PCR, desired amplification was recorded in $4 \mathrm{~h}$ post infected blood sample. The faint band in (Fig.10) in the lane for sample of $4 \mathrm{~h}$ post infection and absence of gene amplification in (Fig. 10) for sample of $4 \mathrm{~h}$ post infection was due to lower amount of 
the bacterial DNA in the samples and dilution of bacterial DNA, respectively. A strong positive band of DNA was seen when PCR was performed with undiluted direct blood sample of $4 \mathrm{~h}$ post infection. The study also concluded that $P$. multocida $\mathrm{B}: 2$ specific $\mathrm{PCR}$ was more sensitive than $P$. multocida gene and $P$. multocida type $\mathrm{B}$ gene amplification in PCR.

No clinical symptom of dullness, moribund state could be noticed in mice even up to $12 \mathrm{~h}$ post infection. Therefore, the blood samples of $8 \mathrm{~h}$ post infection could also be considered as samples collected before the onset of the disease. There was complete agreement in results of bacterial isolation, PCR and The ELISA test recorded with sample of $8 \mathrm{~h}$ post infection.

The study demonstrated development of a sensitive, specific monoclonal antibody based sandwich ELISA for clinical diagnosis of HS which can also be used for early diagnosis of the disease, before onset of clinical symptoms.

\section{References}

Albalasmeh, A.A., Berhe, A.A. and Ghezzehei, T.A. 2013. A new method for rapid determination of carbohydrate and total carbon concentrations using UV spectrophotometry. Carbohydrate polymers. 97: 253-261.

Anon 2004 Development of a monoclonal antibody and outer membrane protein (s) based ELISA kit for monitoring immune status of animals vaccinated against hemorrhagic septicemia. Project completion report (18 Sep-17Sep 2004 Ed. Arvind Kumar and N.K. Kakkar. Department of Veterinary Microbiology, C.C.S. H.A.U. Hisar, Haryana, India.

Benkirane, A. and De Alwis, M.C.L. 2002.
Hemorrhagic septicemia, its significance, prevention and control in Asia. Vet. Med-Czech. 47: 234-40.

Boekema, B.K.H.L., Putten, J.P.M.V., Stockhofe-Zurwieden, N., and Smith, H.E. 2004. Host Cell Contact-Induced Transcription of the Type IV Fimbria Gene Cluster of Actinobacillus pleuropneumoniae. Infecion. Immun. 72 (2): 691-700.

Boyce, J.D. and Adler, B. 2006. How does Pasteurella multocida respond to the host environment. Current Opin. Microbiol. 9: 117-122.

Brickell, S.K., Thomas, L.M., Long, K.A., Panaccio, M. and Widders, P.R. 1998 Development of a PCR test based on a gene region associated with the pathogenicity of Pasteurella multocida serotype B:2, the causal agent of hemorrhagic septicaemia in Asia. Vet. Microbiol. 59: 295-307.

Buxton, A. and Fraser, G. 1977. Animal Microbiology. Vol.1. Blackwell Scientific Publications, Oxford London.

Carter, G.R. 1955. Studies on P. multocida. A haemagglutination test for identification of serological types. Am. J. Vet. Res. 16: 481-484.

Carter, G.R. and De Alwis, M.C.L. 1989. Haemorrhagic Septicaemia. In: Pasteurella and Pasteurellosis. Eds. C. Adlam, \& J.M. Rutter. Academic Press Limited, London.131-160.

De Alwis, M.C.L. 1981. Mortality of cattle and buffaloes in Sri Lanka due to haemorrhagic septicaemia. Tropic. Anim. Health Prod. 13: 195-202.

De Alwis, M.C.L. 1992a Haemorrhagic septicaemia - A general review. Br. Vet. J. 148: 99-112.

De Alwis, M.C.L. 1992b Pasteurellosis in Production Animals: A Review. In: Pasteurellosis in Production Animals, ACIAR Proceedings No. 43, Eds. B.N. Pattern, T.L. Spencer, R.B. Johnson, D. 
Hoffman, L. Lehane. 11-18. ACIAR, Bali, Indonesia.

De Alwis, M.C.L. 1999 Haemorrhogic septicemia. Australian Center for International Agricultural Research (ACIAR) Monograph no. 57. ACIAR, Canberra, Australia.

Doughty, S.W., Ruffolo, C.G. and Adler, B. 2000. The type 4 fimbrial subunit gene of Pasteurella multocida. Vet. Microbiol. 72(1-2): 79-90.

Heddleston, K.L., Gallagher, J.E. and Rebers, P.A. 1972. Fowl cholera: gel diffusion precipitin test for serotyping Pasteurella multocida from avian species. Avian Dis. 16: 925-936.

Horadagoda, N.U., Hodgson, J.C., Moon, G.M., Wijewardana, T.G. and Eckersall, P.D. 2001. Role of endotoxin in the pathogenesis of haemorrhagic septicaemia in the buffalo. Microbial Pathogenesis. 30 (3): 171-8.

Lister, A.L., Pressler, B., Volpe, $\mathrm{A}$ and Dubovi, E. 2012 Accuracy of a pointof-care ELISA test kit for predicting the presence of protective canine parvovirus and canine distemper virus antibody concentrations in dogs. Vet. J. 193(2): 363-366.

Lorenz, T.C. 2012. Polymerase Chain Reaction: Basic Protocol Plus Troubleshooting and Optimization Strategies. J. Vis. Exp. (63), e3998, doi:10.3791/3998.

Muniandy, $\mathrm{N}$ and Mukkur, T.K.S. 1993. Protective potential of purified lipopolysaccharide versus conjugated oligosaccharide of Pasteurella multocida type $\mathrm{B}$ in mice. In: Pasteurellosis in Production Animals. Eds. B.N. Pattern, T.L. Spencer, R.B. Johnson, D. Hoffmann and L. Lehane. An international workshop held at Bali, Indonesia, 10-13. ACIAR Proceedings No. 43: 149-155.

Mutters, R., Mannheim, W. and Bisgaard, M.
1989. Taxonomy of the group. In: Pasteurella and Pasteurellosis. Eds. C.Adlam and J. Rutter. Academic Press, London. Chapter 1, 3-34.

OIE 2012. Haemorrhagic Septicemia: Manual of Diagnostic tests and Vaccines for Terrestial Animals.

Pankaj Kumar 2014. Monoclonal Antibody based search for immunogen of $P$. multocida. $\mathrm{PhD}$ Thesis LLR University of Veterinary \& Animal Sciences, Hisar (India).

Pijoan, C. and Trigo, F. 1990. Bacterial adhesion to mucosal surfaces with special reference to Pasteurella multocida isolates from atrophic rhinitis. Can J Vet Res. 54 Suppl: 16-21.

Radostits, O.M., Gay, C.C., Hinchcliff, K.W. and Constable, P.D. 2007. Veterinary Medicine. 10th edition. 921-923. Saunders, Philadelphia.

Roux, K.H. 2003. Optimization and Troubleshooting in PCR. Adapted from PCR Primer: A Laboratory Manual, 2nd edition. Eds. Dieffenbach and Dveksler. CSHL Press, Cold Spring Harbor, NY, USA, 2003.

Ruffolo, C.G., Tennent, J.M., Michalski, W.P. and Adler, B. 1997. Identification, purification, and characterization of the type 4 fimbriae of Pasteurella multocida. Infect Immun. 65: 339-343.

Singh, R., Tewari, K., Nandakumar, P., Marla, S. and Rao, V.D.P. 2011. Molecular characterization and computational analysis of the major outer membrane protein $(\mathrm{ompH})$ gene of Pasteurella multocida P52. Vet. Arhiv. 81: 211-222.

Singh, V.P., Sinha, D.K., Gupta, S.K. and Chauhan, R.S. 2008. Prevalence of H.S. in India. Vth Annual Scientist Meet on Haemorrhagic Septecaemia at Guahati, 5-6th Sept, 2008.

Tanner, F.W. A. 1948. Textbook of Microorganisms Bacteriology. 4th 
edition, John Wiley \& Sons, New York, Inc., 78-79.

Tasneem, K., Zamir, B., Ali, S., Gill, J. and Raza, A. 2009. Haemorrhagic septicaemia: a review. Pak. J. Sc. 61 No.1.

Townsend, K.M., Frost, A.J., Lee, C.W., Papadimitriou, J.M. and Dawkins, H.J.S. 1998. Development of PCR assay for specific and type-specific identification of Pasteurella multocida isolated. J. Clin. Microbiol. 36: 10961100.

Verma, R. and Jaiswal, T.N. 1998. Haemorrhagic septicaemia vaccines. Vaccine. 16, 1184-1190.

Wardlaw, A.C. 1985. Practical statistics for experimental biologists. John Wiley \& Sons, New York

Wild, D. and Kusnezow, W. 2005. Seperation systems. The Immunoassay Handbook. Third edition. Ed. D. Wild. Elsevier Ltd.

\section{How to cite this article:}

Ragini Hazari, Arvind Kumar and Sonu Sharma. 2019. Development of a Specific Monoclonal Antibody based Sandwich ELISA for Rapid Detection of Haemorrhagic Septicemia in Bovine Blood. Int.J.Curr.Microbiol.App.Sci. 8(05): 1111-1139.

doi: https://doi.org/10.20546/ijcmas.2019.805.128 